\title{
Perspectives for therapeutic HPV vaccine development
}

Andrew Yang ${ }^{1 \dagger}$, Emily Farmer ${ }^{1+}$, T. C. Wu $u^{1,2,3,4}$ and Chien-Fu Hung ${ }^{1,4,5^{*}}$

\begin{abstract}
Background: Human papillomavirus (HPV) infections and associated diseases remain a serious burden worldwide. It is now clear that HPV serves as the etiological factor and biologic carcinogen for HPV-associated lesions and cancers. Although preventative HPV vaccines are available, these vaccines do not induce strong therapeutic effects against established HPV infections and lesions. These concerns create a critical need for the development of therapeutic strategies, such as vaccines, to treat these existing infections and diseases.

Main Body: Unlike preventative vaccines, therapeutic vaccines aim to generate cell-mediated immunity. HPV oncoproteins E6 and E7 are responsible for the malignant progression of HPV-associated diseases and are consistently expressed in HPV-associated diseases and cancer lesions; therefore, they serve as ideal targets for the development of therapeutic HPV vaccines. In this review we revisit therapeutic HPV vaccines that utilize this knowledge to treat HPV-associated lesions and cancers, with a focus on the findings of recent therapeutic HPV vaccine clinical trials.

Conclusion: Great progress has been made to develop and improve novel therapeutic HPV vaccines to treat existing HPV infections and diseases; however, there is still much work to be done. We believe that therapeutic HPV vaccines have the potential to become a widely available and successful therapy to treat HPV and HPV-associated diseases in the near future.
\end{abstract}

Keywords: Human papillomavirus, HPV, Therapeutic vaccine, Cervical cancer, HPV E6, HPV E7

\section{Background}

Cervical cancer is the fourth most common cancer effecting women worldwide [1]. Human papillomavirus (HPV) accounts for nearly all cases of cervical cancer and is responsible for causing several other cancers including: penile, vaginal, vulval, anal and oropharynx including base of the tongue and tonsils [1-4]. There are over 200 types of HPV [5], which are categorized into high risk, and low risk groups according to their oncogenic potential [6, 7]. Among high risk HPV types, type 16 and type 18 are the most common and carcinogenic. Combined, these two HPV types are responsible for about $70 \%$ of cervical cancer cases [8].

\footnotetext{
* Correspondence: chung2@jhmi.edu

${ }^{\dagger}$ Equal contributors

${ }^{1}$ Department of Pathology, Johns Hopkins University, Baltimore, MD, USA

${ }^{4}$ Department of Oncology, Johns Hopkins University, Baltimore, MD, USA

Full list of author information is available at the end of the article
}

Identifying HPV as the etiological factor for HPVassociated malignancies has created the opportunity to control those cancers through vaccination and other therapeutic strategies [9]. Vaccines have been traditionally used as a prophylactic measure against infectious diseases. Several successful prophylactic HPV vaccines have been developed targeting the major capsid protein L1 of the viral particle (for review see $[10,11]$ ). Prophylactic vaccines have been successful at preventing healthy patients from acquiring HPV infections as well as previously infected patients from being re-infected; however, they are not able to treat or clear established $\mathrm{HPV}$ infections and HPV-associated lesions (for review see $[10,12])$. One potential treatment method that has been explored to treat and clear existing HPV infections and associated diseases are therapeutic HPV vaccines. Unlike prophylactic HPV vaccines, which are used to generate neutralizing antibodies against viral particles, therapeutic HPV vaccines are used to stimulate cell-

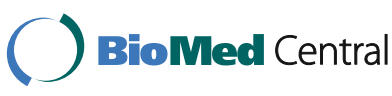

(c) The Author(s). 2016 Open Access This article is distributed under the terms of the Creative Commons Attribution 4.0 International License (http://creativecommons.org/licenses/by/4.0/), which permits unrestricted use, distribution, and reproduction in any medium, provided you give appropriate credit to the original author(s) and the source, provide a link to the Creative Commons license, and indicate if changes were made. The Creative Commons Public Domain Dedication waiver (http://creativecommons.org/publicdomain/zero/1.0/) applies to the data made available in this article, unless otherwise stated. 
mediated immune responses to specifically target and kill infected cells.

Most sexually active women will be infected by HPV at some point in their life. For many women these infections remain asymptomatic and are cleared by the immune system. However, some women can develop persistent HPV infections, which may further develop into low or high-grade cervical intraepithelial neoplasia (CIN) and cervical carcinoma, or regress at any stage $[13,14]$. In many HPV-associated lesions that progress into cancers, the HPV viral DNA genome are found to be integrated into the host's genome. This process often leads to the deletion of many early (E1, E2, E4, and E5) and late (L1 and L2) genes. The deletion of L1 and L2 during the integration process is what renders prophylactic vaccines useless against $\mathrm{HPV}$-associated cancers. In addition, E2 is a negative regulator for the HPV oncogenes E6 and E7. The deletion of E2 during integration leads to elevated expression of E6 and E7 and is thought to contribute to the carcinogenesis of $\mathrm{HPV}$-associated lesions (for review see $[9,15])$. Oncoproteins E6 and E7 are required for the initiation and upkeep of HPVassociated malignancies and are resultantly expressed and present in transformed cells [16]. Furthermore, therapeutic HPV vaccines targeting E6 and E7 can circumvent the problem of immune tolerance against selfantigens because these virus encoded oncogenic proteins are foreign proteins to human bodies. For these reasons HPV oncoproteins E6 and E7 serve as an ideal target for therapeutic HPV vaccines [12].

Although prophylactic HPV vaccines have been a huge success and leap forward in the prevention of HPV infections and HPV-associated diseases, there is still a great HPV-associated disease burden worldwide. As such, there is an urgent need to develop treatments for the control and eradication of existing HPV infections and associated diseases. Our review will cover various therapeutic HPV vaccines in development for the treatment of HPV infections and HPV-associated diseases, including HPV-associated cancers. In addition, we will focus on the findings of latest clinical trials on therapeutic HPV vaccines.

\section{Types of therapeutic HPV vaccines}

Several types of therapeutic vaccines have been developed and tested in preclinical and clinical trials, including live vector, protein or peptide, nucleic acid, and cell-based vaccines (for review see [16]). Importantly, clinical trials are necessary to evaluate whether a therapeutic HPV vaccine is able to control HPV infections and HPV-associated diseases in humans. The majority of these vaccines target HPV oncoproteins E6 and E7 with the aim to deliver E6 and E7 antigens in various forms to antigen presenting cells (APCs) in order to activate
HPV antigen-specific CD8+ cytotoxic T cells or CD4+ helper T cells, respectively (Fig. 1). Importantly, E6 and E7 antigens need to be processed and digested by proteasomes into smaller peptides before they can be presented on the MHC class I molecule of the APCs for the activation of CD8+ T cells. However, not all peptide fragments from the antigenic proteins are loaded on MHC molecules and recognized by antigen-specific $\mathrm{T}$ cells [17]. Only a selected few of these short peptides contain the sequence of antigenic fragments (epitopes) that can bind to the MHC molecule with high affinity and subsequently interact with the $\mathrm{T}$ cell receptor (TCR) of antigen-specific $\mathrm{T}$ cells to elicit an immune response [18-20]. Most therapeutic vaccines have been designed to elicit an immune response against the E7 antigen because it is better characterized immunologically than the E6 antigen in preclinical models.

The following section discusses the characteristics of various therapeutic HPV vaccines being developed and tested. The section summarizes numerous recent clinical trials that have been implemented using various types of therapeutic HPV vaccines against HPV-associated lesions and malignancies. Table 1 summarizes the clinical trials on therapeutic HPV vaccines described in this section. In addition, Table 2 lists several ongoing clinical trials evaluating the efficacy of therapeutic HPV vaccines against HPV-associated diseases.

\section{Live vector-based vaccines}

Live vector-based vaccines are often categorized as either bacterial or viral vectors depending on their vector platform. These vectors replicate within the body and facilitate the spread of the antigen $[12,16]$. Live vector-based therapeutic HPV vaccines are highly immunogenic and can induce strong cellular and humoral immune responses (for review see [16]). They can also deliver E6 and E7 antigens to APCs to stimulate antigen presentation through MHC class I and II. Unfortunately, live vector-based vaccines pose a potential safety risk, particularly in immunocompromised individuals [12]. Additionally, the immune response efficacy after repeated immunization using the same vector is limited [12, 21, 22].

Bacterial vectors Several bacterial vectors have been selected for the development of therapeutic HPV vaccines including Listeria monocytogenes, Lactobacillus lactis, Lactobacillus plantarum, and Lactobacillus casei [23-26]. Listeria has been recognized as a promising vector because of its ability to infect macrophages and secrete listeriolysin O (LLO), a pore-forming toxin, to evade phagosomal lysis [27]. Because it is able to evade phagosomal lysis, Listeria is able to replicate in the cytoplasm of the host cell. This ability further allows the bacteria to be present in both 


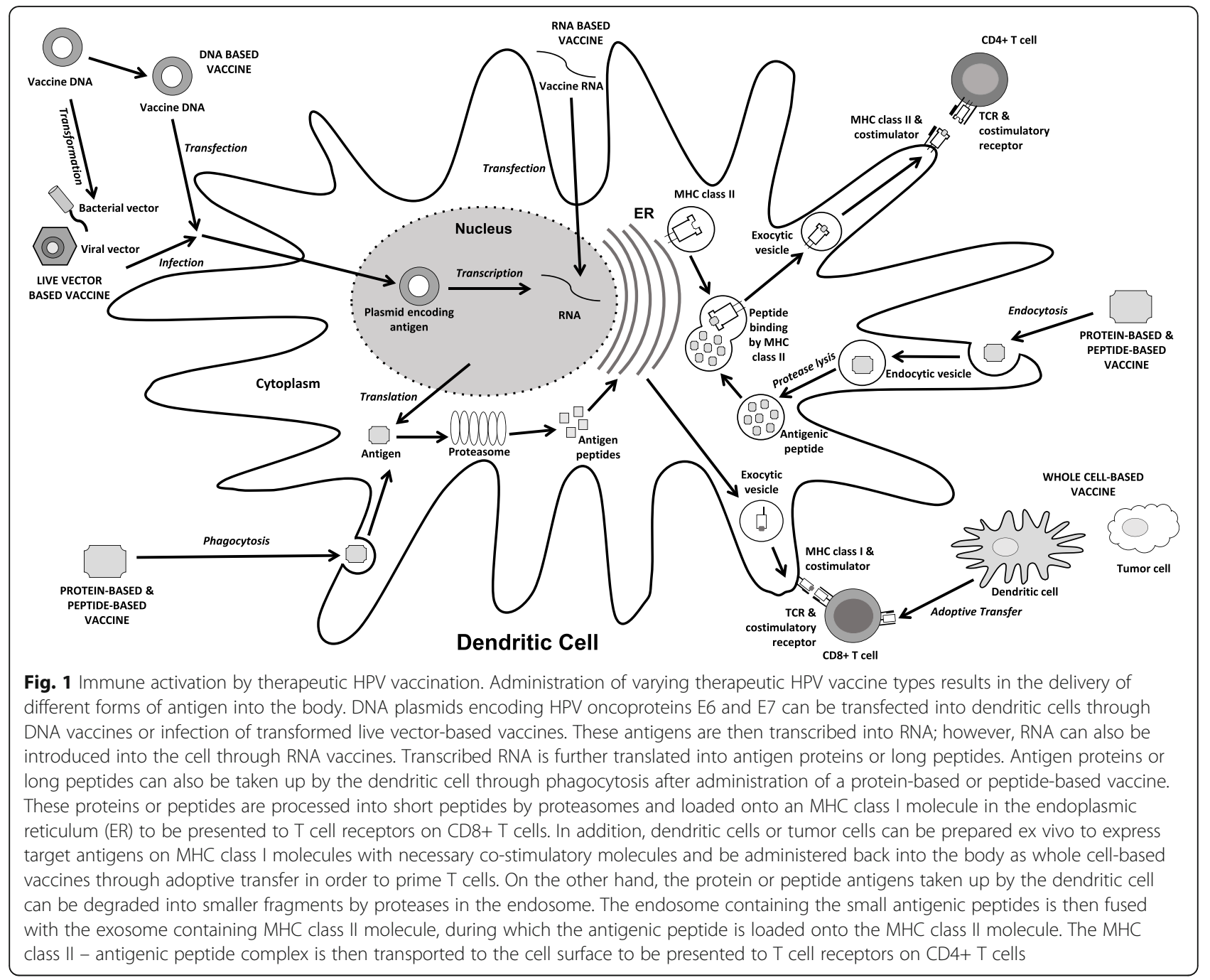

cytoplasm and endosomal compartments allowing the antigen peptides in the bacteria to be presented on both MHC class I to cytotoxic T cells and MHC class II to T helper cells $[12,26,28,29]$.

The first clinical use of a listeria-based therapeutic HPV vaccine was reported in 2009 [30]. The vaccine Lm-LLO-E7 (also known as ADXs11-001 or ADXSHPV) contains prfA-defective Lm strain, transformed with HPV16 E7 antigen and a fragment of nonhemolytic LLO [31]. The phase I trial tested the safety of Lm-LLOE7 in 15 patients with metastatic, refractory, or recurrent advanced squamous cell carcinoma of the cervix. Patients received the vaccine intravenously, followed by IV supplementation of $500 \mathrm{mg}$ of ampicillin 5 days after vaccination, followed by a 10-day oral course of ampicillin $(500 \mathrm{mg})$. The vaccine was well tolerated by patients; common adverse effects included pyrexia, vomiting, chills, headache and anemia, nausea and tachycardia, and musculoskeletal pain. Furthermore, six patients experienced vaccine-related grade 3 adverse events.
Peripheral blood mononuclear cells (PBMCs) were collected from patients and tested, showing an increase in E7-specific IFN $\gamma+\mathrm{T}$ cells in three patients after vaccination. Reduction in total tumor size was observed in four patients, suggesting that Lm-LLO-E7 may have therapeutic effects in controlling cancer progression. The therapeutic potential demonstrated by the Lm-LLo-E7 vaccine has prompt the scientists to plan and design additional clinical trials to further determine the efficacy of this vaccine, including a phase II trial in patients with persistent, recurrent, loco-regional or metastatic anal cancer or HPV+ squamous cell carcinoma of the rectum (NCT02399813), a phase II trial in patients with HPV+ OPC before resection (NCT02002182), a phase I/II trial in patients with locally advanced or metastatic cervical or HPV+ head and neck cancer with or without MED14736 chemobile treatment (NCT02291055), and a phase II trial in patients with persistent or recurrent squamous or non squamous cell carcinoma of the cervix (NCT01266460). 
Table 1 Different forms of therapeutic HPV vaccines recently used in clinical trials

\begin{tabular}{|c|c|c|c|c|c|c|c|}
\hline Vaccine & Antigen(s) & Construct & Organization & Trial design & Outcome & Side effects & Reference \\
\hline \multicolumn{8}{|c|}{ Bacterial Vector Based } \\
\hline $\begin{array}{l}\text { Lm-LLo-E7 } \\
\text { (ADXS11-001; } \\
\text { ADXS-HPV) }\end{array}$ & HPV-16 E7 & $\begin{array}{l}\text { prfA-defective Listeria } \\
\text { monocytogenes strain } \\
\text { transformed with plasmid } \\
\text { encoding HPV-16 E7 } \\
\text { antigen fused to a f } \\
\text { ragment of nonhemolytic } \\
\text { listeriolysin O (LLO) }\end{array}$ & Advaxis, Inc. & $\begin{array}{l}\text { Phase I in patients with } \\
\text { metastatic, refractory or } \\
\text { recurrent, advanced } \\
\text { squamous cell carcinoma } \\
\text { of the cervix ( } 15 \text { patients) }\end{array}$ & $\begin{array}{l}\text { Increase in E7-specific T cells } \\
\text { detected in PBMCs of three } \\
\text { patients. } \\
\text { Reduction in tumor size } \\
\text { observed in } 4 \text { patients. }\end{array}$ & $\begin{array}{l}\text { Pyrexia, vomiting, chills, } \\
\text { headache, anemia, } \\
\text { nausea, tachycardia, } \\
\text { muscle and skeletal pain. }\end{array}$ & {$[30]$} \\
\hline GLBL101C & HPV16-E7 & $\begin{array}{l}\text { Recombinant Lactobacillus } \\
\text { casei expressing modified } \\
\text { version of HPV16-E7 }\end{array}$ & GENOLAC BL Corp & $\begin{array}{l}\text { Phase } 1 / \text { /la in HPV16+ CIN3 } \\
\text { patients (17 patients) }\end{array}$ & $\begin{array}{l}\text { Significant increase in E7-CMI } \\
\text { in cervical vaginal tract. } \\
9 \text { patients experienced disease } \\
\text { regression to CIN2, and } 5 \\
\text { further regressed to LSIL }\end{array}$ & $\begin{array}{l}\text { No major side effects } \\
\text { observed. }\end{array}$ & {$[32]$} \\
\hline \multicolumn{8}{|l|}{ Viral Vector Based } \\
\hline \multirow[t]{3}{*}{ TA-HPV } & HPV-16/18 E6/E7 & $\begin{array}{l}\text { Recombinant Vaccinia } \\
\text { virus }\end{array}$ & $\begin{array}{l}\text { European Organization for } \\
\text { Research and Treatment of } \\
\text { Cancer (EORTC) }\end{array}$ & $\begin{array}{l}\text { Phase } 1 / I \text { in patients with } \\
\text { advanced stage of cervical } \\
\text { cancer (8 patients) }\end{array}$ & $\begin{array}{l}\text { Vaccination induced } \\
\text { HPV-specific cytotoxic T } \\
\text { lymphocyte immune response } \\
\text { in } 28 \% \text { of participants ( } 3 \text { out } \\
\text { of } 8 \text { ). } 2 \text { patients showed tumor } \\
\text { free condition at } 15 \text { and } \\
21 \text { months after vaccination. }\end{array}$ & $\begin{array}{l}\text { Single dose generated } \\
\text { mild and tolerable } \\
\text { toxicity }\end{array}$ & {$[46]$} \\
\hline & & & & $\begin{array}{l}\text { Phase I in patients with } \\
\text { clinical International } \\
\text { Federation of Gynecology } \\
\text { and Obstetrics (FIGO) stage } \\
\text { lb or Ila cervical cancer } \\
\text { who will undergo radical } \\
\text { hysterectomy ( } 29 \text { patients) }\end{array}$ & $\begin{array}{l}\text { After a single vaccination } \\
\text { HPV-specific CTLs were found } \\
\text { in } 4 \text { patients. } 8 \text { patients ( } 28 \% \text { ) } \\
\text { developed HPV-specific } \\
\text { serological responses. }\end{array}$ & $\begin{array}{l}\text { Mild to moderate local } \\
\text { toxicity }\end{array}$ & {$[54]$} \\
\hline & & & & $\begin{array}{l}\text { Phase II in patients ages } \\
42-54 \text { with high-grade } \\
\text { HPV-positive vulval or } \\
\text { vaginal intraepithelial } \\
\text { neoplasia of up to } 15 \\
\text { years duration (12 patients) }\end{array}$ & $\begin{array}{l}5 \text { of } 12 \text { (42\%) patients showed } \\
\text { at least } 50 \% \text { reduction in total } \\
\text { lesion diameter over } 24 \text { weeks } \\
\text { with } 1 \text { patient showing complete } \\
\text { regression of lesion. Overall, } \\
83 \% \text { of women showed some } \\
\text { average decrease in lesion size } \\
\text { of } 40 \% \text {. All patients showed an } \\
\text { increased lgG titer and T-cell } \\
\text { response to the vaccinia virus. }\end{array}$ & $\begin{array}{l}\text { A local reaction at the } \\
\text { site of vaccination } \\
\text { between day } 7-10 \text { was } \\
\text { common and } 2 \text { patients } \\
\text { had temporarily limited } \\
\text { arm movement. }\end{array}$ & {$[55]$} \\
\hline TG4001 & HPV-16 E6/E7 & $\begin{array}{l}\text { Recombinant modified } \\
\text { vaccinia Ankara-expressing } \\
\text { HPV-16 E6, E7, and IL-2 }\end{array}$ & Transgene/roche & $\begin{array}{l}\text { Phase I in HPV16+ CIN2/3 } \\
\text { patients ( } 21 \text { patients) }\end{array}$ & $\begin{array}{l}\text { Ten of } 21(48 \%) \text { showed } \\
\text { disease regression, HPV DNA } \\
\text { clearance in eight patients and } \\
\text { mRNA clearance in seven } \\
\text { patients }\end{array}$ & $\begin{array}{l}\text { Inflammation, pruritus, } \\
\text { edema, lymphadenopathy, } \\
\text { fever, headache, asthenia, } \\
\text { bone pain, vaginal } \\
\text { discharge }\end{array}$ & [47] \\
\hline MVA E2 & HPV-16 E2 & $\begin{array}{l}\text { Recombinant Modified } \\
\text { Vaccinia Ankara encoding } \\
\text { E2 from BPV }\end{array}$ & $\begin{array}{l}\text { Instituto Mexicano del } \\
\text { Seguro Social }\end{array}$ & $\begin{array}{l}\text { Phase III in patients with } \\
\text { HPV-induced AGIN (1176 }\end{array}$ & $\begin{array}{l}90 \% \text { lesion clearance in } \\
\text { female treated patient and } \\
100 \% \text { lesion clearance in male }\end{array}$ & $\begin{array}{l}\text { Headache, flu-like } \\
\text { symptom, fever, }\end{array}$ & [53] \\
\hline
\end{tabular}


Table 1 Different forms of therapeutic HPV vaccines recently used in clinical trials (Continued)

\begin{tabular}{|c|c|c|c|c|c|c|}
\hline & & & & $\begin{array}{l}\text { female patients and } 180 \\
\text { male patients) }\end{array}$ & $\begin{array}{l}\text { treated patients. Antibody and } \\
T \text { cell responses observed in all } \\
\text { tested patients. }\end{array}$ & $\begin{array}{l}\text { chills, abdominal } \\
\text { pain, joint pain. }\end{array}$ \\
\hline \multicolumn{7}{|c|}{ Peptide/Protein Based } \\
\hline \multirow[t]{5}{*}{ HPV16-SLP } & HPV-16 E6/E7 & $\begin{array}{l}\text { Combination of nine } \\
\text { HPV-16 E6 and four } \\
\text { HPV-16 E7 synthetic } \\
\text { peptides with incomplete } \\
\text { Freund's adjuvant }\end{array}$ & ISA Pharmaceuticals & $\begin{array}{l}\text { Phase II in patients with } \\
\text { HPV16+ VIN3 (20 patients) }\end{array}$ & $\begin{array}{l}15 \text { patients had objective } \\
\text { clinical response at } 12 \text { months. } \\
9 \text { complete responses and } 6 \\
\text { partial response. } 85 \% \text { with } \\
\text { circulating HPV- } 16 \text { specific } \\
\text { T cells. } 83 \% \text { had CMl against } \\
\text { HPV- } 16 .\end{array}$ & $\begin{array}{l}\text { Local swelling, redness, } \\
\text { increased skin } \\
\text { temperature, pain at } \\
\text { vaccination site, fever, } \\
\text { flu like symptoms, chills, } \\
\text { and tiredness. }\end{array}$ \\
\hline & & & & $\begin{array}{l}\text { Phase II study in patients } \\
\text { with HPV16+ HSIL } \\
\text { (9 patients) }\end{array}$ & $\begin{array}{l}\text { All vaccinated patients showed } \\
\text { strong HPV-specific T cell } \\
\text { response after vaccination. } \\
\text { Change in patterns of immune } \\
\text { infiltrate. }\end{array}$ & $\begin{array}{l}\text { Itching, redness, swelling, } \\
\text { and pain at injection site, } \\
\text { headache, diarrhea, } \\
\text { fatigue/dizziness, nausea, } \\
\text { chills, myalgia, rash, fever, } \\
\text { urticarial, edema. }\end{array}$ \\
\hline & & & & $\begin{array}{l}\text { Phase II in patients } \\
\text { HPV16+ advanced or } \\
\text { recurrent gynecological } \\
\text { carcinoma (20 patients) }\end{array}$ & $\begin{array}{l}9 \text { patients with HPV- } 16 \text { specific } \\
\text { immune response. Duration of } \\
\text { survival correlates with } \\
\text { magnitude of T cell response. }\end{array}$ & $\begin{array}{l}\text { Injection site reaction, } \\
\text { fever, chills, fatigue, } \\
\text { nausea, flue-like } \\
\text { symptom }\end{array}$ \\
\hline & & & & $\begin{array}{l}\text { Phase II in patients with } \\
\text { low-grade abnormalities } \\
\text { of the cervix ( } 50 \text { patients) }\end{array}$ & $\begin{array}{l}97 \% \text { of vaccinated patients } \\
\text { generated HPV } 16 \text {-specific CMI }\end{array}$ & $\begin{array}{l}\text { Flu-like symptom, } \\
\text { injection site reaction. }\end{array}$ \\
\hline & & & & $\begin{array}{l}\text { Observational study in } \\
\text { patients with advanced, } \\
\text { recurrent, or metastatic } \\
\text { cervical cancer scheduled } \\
\text { to receive standard } \\
\text { Carboplatin/Paclitaxel } \\
\text { chemotherapy } \\
\text { (18 patients). }\end{array}$ & $\begin{array}{l}11 \text { of } 12 \text { vaccinated patients } \\
\text { induced proliferative T cell } \\
\text { responses }\end{array}$ & $\begin{array}{l}\text { Chemotherapy related } \\
\text { anemia, thrombocytopenia, } \\
\text { leucopenia, neutropenia, } \\
\text { and alopecia. Cancer } \\
\text { related shortness of breath, } \\
\text { pulmonary embolism, } \\
\text { abdominal pain, } \\
\text { gastroenteritis, erysipelas, } \\
\text { hydronephrosis }\end{array}$ \\
\hline GL-0810 & HPV-16 antigen & $\begin{array}{l}\text { HPV-16 } \\
\text { immunomodulatory } \\
\text { peptide with adjuvant } \\
\text { Montanide and GM-CSF }\end{array}$ & Gliknik Inc. & $\begin{array}{l}\text { Phase I in patients with } \\
\text { recurrent/metastatic } \\
\text { squamous cell carcinoma } \\
\text { of the head and neck } \\
\text { ( } 5 \text { patients) }\end{array}$ & $\begin{array}{l}80 \% \text { of patients who received } \\
\text { four vaccinated developed T } \\
\text { cell and antibody response. } \\
\text { Progression free and overall } \\
\text { survival is 8- to } 196 \text { days } \\
\text { respectively }\end{array}$ & $\begin{array}{l}\text { Erythema, itching, and } \\
\text { pain at injection site }\end{array}$ \\
\hline $\begin{array}{l}\text { Pepcan }+ \\
\text { Candin }\end{array}$ & HPV-16 E6 & $\begin{array}{l}\text { HPV16 E6 peptides } \\
\text { combined with Candida } \\
\text { skin testing reagent } \\
\text { candin. }\end{array}$ & University of Arkansas & $\begin{array}{l}\text { Phase I study in patients } \\
\text { with biopsy-confirmed } \\
\text { HSIL (31 patients) }\end{array}$ & $\begin{array}{l}45 \% \text { patients experienced } \\
\text { histological disease regression. }\end{array}$ & $\begin{array}{l}\text { Mild to moderate } \\
\text { injection site reaction. }\end{array}$ \\
\hline $\begin{array}{l}\text { GTL001 } \\
\text { (ProCervix) }\end{array}$ & $\begin{array}{l}\text { HPV-16 and } \\
\text { HPV-18 }\end{array}$ & $\begin{array}{l}\text { Recombinant HPV16 and } \\
\text { HPV18 E7 proteins fused } \\
\text { to catalytically inactive }\end{array}$ & Genticel & $\begin{array}{l}\text { Phase I trial in patients } \\
\text { positive for HPV-16 or } \\
\text { HPV-18 infection but with }\end{array}$ & $\begin{array}{l}\text { Patients in cohort } 4(n=9) \\
\text { who received 600ug GTL001 } \\
\text { powder + imiquimod }\end{array}$ & $\begin{array}{l}\text { Injection site reactions } \\
\text { including pain, swelling, } \\
\text { induration, tenderness, } \\
\text { and itching }\end{array}$ \\
\hline
\end{tabular}

Phase II study in patients with HPV16+ HSIL

Phase II in patients

HPV16+ advanced or

oplatin/Paclitax

chemotherapy

Phase I in patients with

recurrent/metastatic

squamous cell carcinom

of the head and neck

ed developed T

cell and antibody response.

survival is 8- to 196 days

Phase I study in patients

with biopsy-confirmed

Phase I trial in patients

HPV-18 infection but with who received 600ug GTL001

and itching 
Table 1 Different forms of therapeutic HPV vaccines recently used in clinical trials (Continued)

\begin{tabular}{|c|c|c|c|c|c|c|c|}
\hline & & $\begin{array}{l}\text { Bordetella pertussis CyaA } \\
\text { expressed in E. coli }\end{array}$ & & $\begin{array}{l}\text { normal cytology } \\
\text { (47 patients) }\end{array}$ & $\begin{array}{l}\text { experienced the highest } \\
\text { HPV16/18 clearance rate. }\end{array}$ & & \\
\hline \multirow[t]{2}{*}{ TA-CIN } & HPV-16 E6/E7/L2 & $\begin{array}{l}\text { HPV16 E6E7L2 fusion } \\
\text { protein }\end{array}$ & Xenova Research Limited & $\begin{array}{l}\text { Phase I in healthy patients } \\
\text { (40 subjects) }\end{array}$ & $\begin{array}{l}\text { TA-CIN specific lgG in } 24 \text { of } 32 \\
\text { vaccinated patients. } 25 \text { of } 32 \\
\text { vaccinated patients generated } \\
\text { CMI. }\end{array}$ & $\begin{array}{l}\text { Injection site reaction, } \\
\text { tenderness. Headache } \\
\text { and fatigue }\end{array}$ & [70] \\
\hline & & & & $\begin{array}{l}\text { Phase II with VIN2/3 } \\
\text { patients (19 patients) }\end{array}$ & $\begin{array}{l}63 \% \text { lesion response } 1 \text { year } \\
\text { after vaccination. Significant } \\
\text { increase. } \\
\text { Significant CMl observed in } \\
\text { lesion responders. }\end{array}$ & $\begin{array}{l}\text { Local reaction associated } \\
\text { with imiquimod. }\end{array}$ & {$[72]$} \\
\hline \multirow[t]{2}{*}{$\begin{array}{l}\text { TA-CIN + TA- } \\
\text { HPV }\end{array}$} & $\begin{array}{l}\text { HPV-16/18 E6/ } \\
\text { E7/L2 }\end{array}$ & $\begin{array}{l}\text { HPV16 E6E7L2 fusion } \\
\text { protein and vaccinia } \\
\text { virus with HPV16/18 E6/E7 }\end{array}$ & Celtic Pharma & $\begin{array}{l}\text { Phase I with HPV16+ VIN } \\
\text { patient (10 patients) }\end{array}$ & $\begin{array}{l}\text { Partial or complete clinical } \\
\text { response in } 2 \text { patients. All but } 1 \\
\text { patient showed HPV-16 specific } \\
\text { lgG and/or T cell responses. }\end{array}$ & Pain at injection site. & [69] \\
\hline & & & & $\begin{array}{l}\text { Phase II with HPV16+ } \\
\text { high-grade AGIN Patients } \\
\text { (29 patients) }\end{array}$ & $\begin{array}{l}17 \text { patients showed TA-CIN } \\
\text { induced T cell responses. } 11 \\
\text { generated HPV-16/18 E6 and/or } \\
\text { E7 specific T cells. } 14 \text { with IgG } \\
\text { response to HPV-16 E7. }\end{array}$ & N/A & [71] \\
\hline \multicolumn{8}{|l|}{ Nucleotide Based } \\
\hline $\begin{array}{l}\text { pNGVL4a-sig/ } \\
\text { E7(detox)/ } \\
\text { HSP70+TA- } \\
\text { HPV }\end{array}$ & HPV-16/18 E6/E7 & $\begin{array}{l}\text { Plasmid encoding } \\
\text { mutated form of HPV16-E7 } \\
\text { linked to sig and HSP70 } \\
\text { and vaccinia virus with } \\
\text { HPV16/18 E6/E7 }\end{array}$ & $\begin{array}{l}\text { Sidney Kimmel } \\
\text { Comprehensive Cancer } \\
\text { Center }\end{array}$ & $\begin{array}{l}\text { Phase I with HPV16+ CIN3 } \\
\text { Patients ( } 12 \text { patients) }\end{array}$ & $\begin{array}{l}58 \text { \% vaccinated patients have } \\
\text { generated HPV-16 E7-specific } \\
\text { CMI. Increase CD } 8+\text { T cell } \\
\text { infiltration to lesions. }\end{array}$ & $\begin{array}{l}\text { Tenderness, local site } \\
\text { reaction, blister, } \\
\text { erythema, pruritus }\end{array}$ & {$[79]$} \\
\hline $\begin{array}{l}\text { pNGVLLa-CRT/ } \\
\text { E7(detox) }\end{array}$ & HPV-16 E7 & $\begin{array}{l}\text { Plasmid encoding } \\
\text { mutated form of } \\
\text { HPV16-E7 linked to CRT }\end{array}$ & $\begin{array}{l}\text { Sidney Kimmel } \\
\text { Comprehensive Cancer } \\
\text { Center }\end{array}$ & $\begin{array}{l}\text { Phase I with HPV16+ } \\
\text { CIN2/3 Patients } \\
\text { (32 patients) }\end{array}$ & $\begin{array}{l}30 \% \text { vaccinated patients } \\
\text { experienced histological } \\
\text { regression to CIN1 or less. } \\
\text { Increase in intraepithelial } \\
\text { C } 8+\text { T cells infiltrate after } \\
\text { vaccination. }\end{array}$ & Injection site reaction. & [81] \\
\hline GX-188E & HPV-16/18 E6/E7 & $\begin{array}{l}\text { Plasmid encoding fusion } \\
\text { protein of HPV 16/18 E6/E7 } \\
\text { linked to Flt3L and tpa }\end{array}$ & Genexine, Inc & $\begin{array}{l}\text { Phase I in patients with } \\
\text { HPV } 16 / 18+\text { CIN3 } \\
\text { (9 patients) }\end{array}$ & $\begin{array}{l}\text { All patients displayed } \\
\text { enhanced HPV-specific CMI. } \\
7 \text { patients demonstrated } \\
\text { complete lesion regression by } \\
\text { the end of the trial. }\end{array}$ & $\begin{array}{l}\text { Chills, injection site pain, } \\
\text { swelling, hypoesthesia, } \\
\text { headache, fatigue, rhinitis }\end{array}$ & [82] \\
\hline \multirow[t]{2}{*}{ VGX-3100 } & HPV-16/18 E6/E7 & $\begin{array}{l}\text { Mixture of two plasmids } \\
\text { encoding optimized } \\
\text { consensus of E6 and E7 } \\
\text { antigen of HPV } 16 \text { and } 18\end{array}$ & Inovio Pharmaceuticals & $\begin{array}{l}\text { Phase I with } \\
\text { HPV16/18 + CIN2/3 } \\
\text { Patients (18 patients) }\end{array}$ & $\begin{array}{l}\text { HPV-specific CMI observed in } \\
78 \% \text { patients and HPV-specific } \\
\text { humoral response observed in } \\
\text { all patients. }\end{array}$ & $\begin{array}{l}\text { Injection site reaction, } \\
\text { pain, fever, tenderness. }\end{array}$ & {$[85]$} \\
\hline & & & & $\begin{array}{l}\text { Phase Ilb with } \\
\text { HPV16/18 + CIN2/3 Patients } \\
\text { (167 patients) }\end{array}$ & $\begin{array}{l}49.5 \% \text { vaccinated patient } \\
\text { demonstrated regression } \\
\text { compared to } 30.6 \% \text { in } \\
\text { placebo group. Vaccinations }\end{array}$ & $\begin{array}{l}\text { Injection site reaction, } \\
\text { fatigues, headache, } \\
\text { lyalgia, nausea, } \\
\text { arthralgia, erythema }\end{array}$ & [86] \\
\hline
\end{tabular}

Nucleotide Based
Phase II with HPV16+ high-grade AGIN Patients (29 patients)

$$
\begin{aligned}
& \text { generated HPV-16/18 E6 and/or } \\
& \text { E7 specific T cells. } 14 \text { with IgG } \\
& \text { response to HPV-16 E7. }
\end{aligned}
$$


Table 1 Different forms of therapeutic HPV vaccines recently used in clinical trials (Continued)

Whole Cell Based

\begin{tabular}{|c|c|c|c|c|c|c|c|}
\hline $\mathrm{DC}+\mathrm{KLH}$ & $\begin{array}{l}\text { HPV-16 and } \\
\text { HPV-18 E7 }\end{array}$ & $\begin{array}{l}\text { Dendritic Cells pulsed } \\
\text { with HPV- } 16 \text { and HPV-18 } \\
\text { E7 and keyhole limpet } \\
\text { hemocyanin }\end{array}$ & National Institutes of Health & $\begin{array}{l}\text { Phase I in patients with } \\
\text { stage Ib or lla cervical } \\
\text { cancer (10 patients) }\end{array}$ & $\begin{array}{l}\text { Increase in HPV-specific } \\
\text { humoral and CD4+ T cell } \\
\text { responses observed, but } \\
\text { not CD8+ T cell responses. }\end{array}$ & $\begin{array}{l}\text { Local site reaction, } \\
\text { erythema, swelling, } \\
\text { pruritus }\end{array}$ & [101] \\
\hline DC & HPV antigens & $\begin{array}{l}\text { DC pulsed with HPV+ } \\
\text { tumor lysate }\end{array}$ & $\begin{array}{l}\text { Department of } \\
\text { Biotechnology (DBT, Govt. of } \\
\text { India) }\end{array}$ & $\begin{array}{l}\text { Phase I in in patients with } \\
\text { HPV+ advanced, recurrent } \\
\text { cervical cancer (14 patients) }\end{array}$ & $\begin{array}{l}\text { No significant increase in } \\
\text { lymphocyte proliferation } \\
\text { observed. Lack of biopsy } \\
\text { sample and small sample } \\
\text { size prevent definite } \\
\text { conclusions. }\end{array}$ & $\begin{array}{l}\text { Local site reaction, fever, } \\
\text { chills, abdominal } \\
\text { discomfort, vomiting. }\end{array}$ & {$[102]$} \\
\hline
\end{tabular}

enhance T cell and humoral 
Table 2 Ongoing therapeutic HPV vaccine clinical trials

\begin{tabular}{|c|c|c|c|c|c|c|}
\hline Vaccine & Antigen(s) & Construct & Organization & Trial Design & $\begin{array}{l}\text { Estimated Date of Trial } \\
\text { Completion }\end{array}$ & $\begin{array}{l}\text { Clinical Trials.go } \\
\text { Identifier }\end{array}$ \\
\hline \multicolumn{7}{|c|}{$\begin{array}{l}\text { Persistent HPV Infection and Low-Grade Squamous } \\
\text { Intraepithelial Lesion }\end{array}$} \\
\hline PDS0101 & HPV-16 E6/E7 & $\begin{array}{l}\text { R-enantiomer of } \\
\text { 1,2-dioleoyl-3- } \\
\text { trimethylammonium- } \\
\text { propane chloride } \\
+ \text { Peptides HPV-16 } \\
\text { E6 and E7 }\end{array}$ & PDS Biotechnology Corp. & $\begin{array}{l}\text { Phase I in female patients with high risk } \\
\text { HPV infection or CIN1 (18 estimated } \\
\text { patients) }\end{array}$ & $\begin{array}{l}\text { Information not } \\
\text { provided }\end{array}$ & NCT02065973 \\
\hline ProCervix & HPV-16/18 E7 & $\begin{array}{l}2 \text { recombinant } \\
\text { adenylate cyclase (CyaA) } \\
\text { proteins: CyaA-HPV } \\
16 \mathrm{E} 7 \text { \& CyaA-HPV 18E7 }\end{array}$ & Genticel & $\begin{array}{l}\text { Phase II in female patients with } \\
\text { HPV16/18+ infection or ASCUS/LSIL } \\
\text { (220 estimated patients) }\end{array}$ & December 2016 & NCT01957878 \\
\hline \multicolumn{7}{|c|}{$\begin{array}{l}\text { Cervical Intraepithelial Neoplasia (CIN)/High-Grade } \\
\text { Squamous Intraepithelial Lesion }\end{array}$} \\
\hline \multirow[t]{2}{*}{ GX-188E } & $\begin{array}{l}\text { HPV-16/18 } \\
\text { E6/E7 }\end{array}$ & $\begin{array}{l}\text { Plasmid encoding fusion } \\
\text { protein of HPV } 16 / 18 \text { E6/E7 } \\
\text { linked to Flt3L and tpa }\end{array}$ & Genexine, Inc & $\begin{array}{l}\text { Phase II in HPV } 16 / 18+\text { CIN2, CIN2/3, and } \\
\text { CIN3 patients in Eastern Europe (120 } \\
\text { estimated patients) }\end{array}$ & December 2017 & NCT02596243 \\
\hline & & & & $\begin{array}{l}\text { Phase II in HPV 16/18+ CIN3 patients in South } \\
\text { Korea (72 estimated patients) }\end{array}$ & October 2016 & NCT02139267 \\
\hline pNGVL4a-CRT/E7(detox) & HPV-16 E7 & $\begin{array}{l}\text { Plasmid encoding } \\
\text { mutated form of } \\
\text { HPV16-E7 linked to } \\
\text { calreticulin }\end{array}$ & $\begin{array}{l}\text { Sidney Kimmel } \\
\text { Comprehensive Cancer } \\
\text { Center }\end{array}$ & $\begin{array}{l}\text { Phase I in patients with HPV16+ CIN2/3 } \\
\text { (39 estimated patients) }\end{array}$ & March 2017 & NCT00988559 \\
\hline $\begin{array}{l}\text { pNGVL4a-sig/E7(detox)/ } \\
\text { HSP70 + TA-HPV }\end{array}$ & $\begin{array}{l}\text { HPV-16/18 } \\
\text { E6/E7 }\end{array}$ & $\begin{array}{l}\text { Plasmid encoding } \\
\text { mutated form of } \\
\text { HPV16-E7 linked to sig } \\
\text { and HSP70 and vaccinia } \\
\text { virus with HPV16/18 E6/E7 }\end{array}$ & & $\begin{array}{l}\text { Phase I in patients with HPV16+ CIN3 in } \\
\text { combination with topical imiquimod } \\
\text { (48 estimated patients) }\end{array}$ & December 2016 & NCT00788164 \\
\hline $\begin{array}{l}\text { TVGV-1+ } \\
\text { GPI-0100 }\end{array}$ & HPV-16 E7 & $\begin{array}{l}\text { Fusion protein of } \\
\text { HPV-16 E7 and ER } \\
\text { targeting sequence }\end{array}$ & THEVAX Genetics Vaccine Co. & $\begin{array}{l}\text { Phase Ila in patients with HPV induced } \\
\text { cervical HSIL (51 estimated patients) }\end{array}$ & June 2017 & NCT02576561 \\
\hline Pepcan + Candin & HPV-16 E6 & $\begin{array}{l}\text { HPV16 E6 peptides } \\
\text { combined with Candida } \\
\text { skin testing reagent } \\
\text { candin. }\end{array}$ & University of Arkansas & $\begin{array}{l}\text { Phase II in patients with cervical HSIL } \\
\text { (125 estimated patients) }\end{array}$ & August 2020 & NCT02481414 \\
\hline \multicolumn{7}{|c|}{ Anal Intraepithelial Neoplasia (AIN) } \\
\hline $\begin{array}{l}\text { ISA101 } \\
\text { (SLP-HPV-01; HPV16-SLP) }\end{array}$ & HPV-16 E6/E7 & $\begin{array}{l}\text { Combination of nine } \\
\text { HPV-16 E6 and four } \\
\text { HPV-16 E7 synthetic } \\
\text { peptides with } \\
\text { incomplete Freund's } \\
\text { adjuvant }\end{array}$ & ISA Pharmaceuticals & $\begin{array}{l}\text { Phase } 1 / I \text { in HIV+ male patients with } \\
\text { HPV-16+ AIN2/3 (45 estimated patients) }\end{array}$ & February 2018 & NCT01923116 \\
\hline ADXS11-001 (Lm-LLo-E7) & HPV-16-E7 & & Advaxis, Inc. & & March 2017 & NCT02399813 \\
\hline
\end{tabular}

CIN3 patients in Eastern Europe (120

Korea (72 estimated patients)

Phase I in patients with HPV16+ CIN2/3

mutated form of

HPV16-E7 linked to

Plasmid encoding

mutated form of

PV16-E7 linked to sig

virus with HPV16/18 E6/E7

Phase I in patients with HPV16+ CIN3 in

combination with topical imiquimod

March 2017

NCT02399813 
Table 2 Ongoing therapeutic HPV vaccine clinical trials (Continued)

prfA-defective Listeria

monocytogenes strain

transformed with plasmid

encoding HPV-16 E7 antigen

fused to a fragment of

nonhemolytic listeriolysin 0

(LLO)

HPV-Associated Incurable Solid Tumors

ISA101

(SLP-HPV-01; HPV16-SLP)

HPV-16 E6/E

Combination of nine HPV-16

E6 and four HPV-16 E7

synthetic peptides with

incomplete Freund's

adjuvant

DPX-E7

HPV-16 E7

HPV16-E711-19 nanomer

Dana-Farber Cancer Institute

prfA-defective Listeria

monocytogenes strain

transformed with plasmid

encoding HPV-16 E7 antigen

fused to a fragment of

nonhemolytic listeriolysin 0

(LLO)

\begin{abstract}
INO-3112
HPV-16/18

(VGX-3100 + INO-9012) E6/E7
\end{abstract}

Cervical Cancer

ADXS11-001 (Lm-LLo-E7) HPV-16-E7

A defective Listeria

monocytogenes strain

transformed with plasmid

encoding HPV-16 E7 antigen

fused to a fragment of

nonhemolytic listeriolysin

O (LLO)

INO-3112

HPV-16/18 Mixture of three plasmids

encoding optimized

concoding optimized

antigen of HPV 16 and 18

Advaxis, Inc
Phase II trial in patients with persistent,

recurrent, loco-regional, or metastatic

anal cancer or HPV+ squamous cell

carcinoma of the rectum that are either

treatment naive in the metastatic setting

or have progressed or become intoleran

to platinum based therapy (55 estimated

patients)

Phase II in patients with HPV-16+ Incurable solid tumors (oropharyngeal squamous cell carcinoma, cervical, vulvar, vaginal, anal, and penile cancer) as combination therapy with Nivolumab (28 estimated patients)

Phase Ib/II trial in HLA-A*02 positive patients with incurable HPV 16-related oropharyngeal, cervical and anal cancer (44 estimated patients)

Phase II in patients with

HPV+ Oropharyngeal Squamous Cell

Carcinoma before robot-assisted resection

(30 estimated patients)

Phase I/II in patients with locally

advanced or metastatic cervical or

HPV+ Head and nack cancer with or

without MED14736 chemoblie

(66 estimated patients)

Phase I/IIA in patients with HPV

associated head and neck squamous cell

carcinoma (25 estimated patients)

NCT02426892

May 2023

NCT02865135

Phase II in patients with persistent or recurrent squamous or non-squamous

cell carcinoma of the cervix

(67 estimated patients)

Phase I/IIA in female patients with new, recurrent, or persistent cervical cancer

April 2019

NCT02172911 
Table 2 Ongoing therapeutic HPV vaccine clinical trials (Continued)

rable 2 Ongoing therapeutic HPV vaccine clinical trias (Continued,

Phase II in patients with locally advanced

May 2021

NCT02501278

activator expressing IL-12

cervical cancer as combination therapy

with chemoradiation (126 estimated

patients)

\begin{tabular}{|c|c|c|c|c|c|c|}
\hline $\begin{array}{l}\text { ISA101 } \\
\text { (SLP-HPV-01; HPV16-SLP) }\end{array}$ & HPV-16 E6/E7 & $\begin{array}{l}\text { Combination of nine } \\
\text { HPV-16 E6 and four HPV- } 16 \\
\text { E7 synthetic peptides with } \\
\text { incomplete Freund's adjuvant }\end{array}$ & ISA Pharmaceuticals & $\begin{array}{l}\text { Phase } 1 / \| \text { in female patients with } \\
\text { HPV-16+ advanced or recurrent cervical } \\
\text { cancer (48 estimated patients) }\end{array}$ & December 2016 & NCT02128126 \\
\hline $\begin{array}{l}\text { TA-CIN + } \\
\text { GPI-0100 }\end{array}$ & $\begin{array}{l}\text { HPV-16 E6/ } \\
\text { E7/L2 }\end{array}$ & $\begin{array}{l}\text { HPV16 E6E7L2 fusion } \\
\text { protein + GPI-0100 adjuvant }\end{array}$ & $\begin{array}{l}\text { Sidney Kimmel } \\
\text { Comprehensive Cancer } \\
\text { Center }\end{array}$ & $\begin{array}{l}\text { Phase I in patients with HPV16 associated } \\
\text { cervical cancer ( } 30 \text { estimated patients) }\end{array}$ & May 2020 & NCT02405221 \\
\hline
\end{tabular}

AGIN Ano Genital Intraepithelial Neoplasia, AIN Anal intraepithelial Neoplasia, ASCUC atypical squamous cells of undetermined significance, CIN Cervical intraepithelial neoplasia, ER Endoplasmic reticulum, HIV Human immunodeficiency virus, HPV Human papillomavirus, HSIL High-grade squamous intraepithelial lesion, LSIL Low-grade squamous intraepithelial lesion 
A recent study tested the efficacy and safety of oral administration of GLBL101c, a bacterial vector-based therapeutic HPV vaccine. The Phase I/IIa study involved 17 patients with HPV16+ CIN3 lesions [32]. GLBL101c is generated from a recombinant $L$. casei that expresses a modified HPV16-E7 antigen, which is no longer carcinogenic [23]. The bacterial vector-based vaccine was administered to patients through ingestion after it was made into powder and enclosed into capsule form. None of the participating patients in this study experienced serious adverse effects. A significant increase in E7specific cell-mediated immune responses in the cervical vaginal tract was observed in all patients who received the vaccine.

Other attenuated bacterial vectors can also be created through transformation with plasmids containing the genes of interest. For example, Salmonella, Shigella, and Escherichia coli, can deliver plasmid encoding genes of interest to APCs. Previous studies have tested the use of Salmonella for the delivery of HPV16 E7 protein or E7 epitopes to elicit E7-specific responses [33].

Viral vectors Several viral vectors have been examined to deliver HPV E6 and E7 antigens including adenoviruses, adeno-associated viruses, alphaviruses, lentivirus, and vaccinia viruses $[16,34-45]$.

Vaccinia virus is an enveloped, double-stranded DNA virus belonging to the Poxvirus family. Vaccinia virus has a large genome, highly infectious nature, and low likelihood of unregulated integration of foreign DNA into its genome, making it a promising viral vector for vaccine delivery [46].

Several Modified Vaccinia Ankara (MVA)-based therapeutic HPV vaccines have been created and tested in recent years. TG4001 is a suspension of MVATG8042 particles consisting of attenuated recombinant MVA including sequences encoding modified HPV16 E6/E7 and human IL-2. The safety and efficacy of this vaccine was evaluated in 21 patients with HPV16-related CIN2/3 lesions [47]. Each patient received three subcutaneous injections, at 1-week intervals of TG4001 in their thigh. Most adverse effects were mild or moderate, including inflammation, pruritus, edema at the injection site, lymphadenopathy, fever, headache, asthenia, bone pain, and vaginal discharge. Furthermore, HPV16 DNA clearance was observed in 8 out of 10 responders, HPV16 mRNA clearance in 7, and no recurrence of high-grade lesions was observed for 12 months after treatment.

Another MVA-based vaccine, MVA E2 was created to deliver E2 proteins into vaccinated hosts rather than E6 and E7 [48]. The vaccine utilize the knowledge that E2 protein serve as inhibitor for the expression of E6 and E7 oncoproteins, and that the introduction of E2 into the host may suppress the activity of E6 and E7 in HPV- infected host, and subsequently reduce the transforming ability of the infected cells and the survivability of the malignant, HPV-associated tumor cells $[9,15]$. In addition, E2 protein has been shown to arrest cell growth and induce apoptosis of cancer cells [49]. In addition, since some of the HPV-infected cells do not experience the lost of E2 gene during the transformation process (for review see [50-52]), MVA E2 vaccine may also lead to the generation of CD8+ T cells that can target the E2 antigen expressing, HPV-infected cells. Thus, MVA E2 may generate therapeutic antitumor effects against HPV-associated lesions through immunologic and biological mechanisms. MVA E2 was recently tested in a phase III clinical study for the treatment of HPVinduced ano-genital intraepithelial lesions [53], involving a total of 1356 patients (both male and female). Patients were injected locally at the lesion site or into visible lesions. The overall efficacy in this study for treating HPV-induced CIN lesions was around $90 \%$ and all males showed complete eradication of lesions. Additionally, antibodies against HPV-E2 protein and MVA E2 vaccine were identified in the serum of all treated patients and cytotoxic $\mathrm{T}$ cell response that are specific to HPV-transformed cells were observed. The results of this clinical study demonstrate the therapeutic potential of the MVA E2 vaccine in treating HPV+ disease and potentially stimulating the immune system to target HPV-associated intraepithelial lesions.

TA-HPV is a live recombinant vaccinia virus vaccine that encodes oncoproteins E6 and E7 of both HPV type 16 and HPV18. TA-HPV was first used in clinical trial in eight patients with advanced stage cervical cancer [46]. In three patients' TA-HPV induced an HPV-specific cytotoxic $\mathrm{T}$ cell response, and two patients were tumor free at 15 and 21 months after vaccination. In an additional clinical study using TA-HPV, 8 out of 29 patients displayed HPV specific serological responses, but HPVspecific cytotoxic $\mathrm{T}$ cell response was short lived [54]. Another clinical trial administered TA-HPV to 12 patients with HPV16+ vulval intraepithelial neoplasia (VIN) grade III and one patient with HPV16+ vaginal intraepithelial neoplasia (VAIN) grade II [55]. A reduction in $\mathrm{HPV}$-associated lesion size was observed in patients as well as a significant increase in HPV16 E6/ E7-specific T cell response.

As mentioned earlier, one challenge to using live vector-based therapeutic $\mathrm{HPV}$ vaccines is the generation of antibacterial or antiviral immune responses and neutralizing antibodies after initial vaccine exposure. Consequently, this limits the efficacy of multiple vaccine administrations. This issue was partially addressed by a former study, which showed that cyclooxygenase 2 (COX-2) inhibitors may prevent the production of neutralizing antibodies to vaccinia virus [56]. 


\section{Peptide and protein-based vaccines}

Peptide and protein that are derived from HPV antigens are processed by DCs and presented on either $\mathrm{MHC}$ class I or class II molecules to stimulate CD8+ or CD4+ $\mathrm{T}$ cell immune response $[12,57]$. Furthermore, peptide and protein-based vaccines are safe, stable, and easy to produce.

Peptide-based vaccines Although peptide-based vaccines are safe, stable, and easy to produce they have poor immunogenicity and require lipids or other adjuvants, such as chemokines, cytokines, and Toll-like receptor (TLR) ligands, to enhance vaccine potency [57]. These methods help improve the vaccine's ability to activate innate and adaptive immunity and further boost CD8+ $\mathrm{T}$ cell responses (for review see [12]). Unfortunately, peptide-based vaccines are MHC specific, meaning that, for the vaccine to be effective the specific immunogenic epitopes of HPV antigens needs to be identified for each individual. Due to the $\mathrm{MHC}$ specificity required of peptide-based vaccines, they face certain challenges for large scale production and treatment of HPV-associated diseases [58]. One possible solution is the application of overlapping long-peptide vaccines. This method has been proven effective at inducing antigen-specific $\mathrm{T}$ cell responses in several preclinical models, (for review see $[57,58])$.

HPV16 synthetic long-peptide vaccine (HPV16-SLP) and its therapeutic effects have been studied extensively in several clinical trials [59-61]. HPV16-SLP consists of both E6 and E7 overlapping peptides and Montanide ISA-51 as an adjuvant [62]. A recent placebo-controlled, double-blinded phase II study further investigated the capability of HPV16-SLP vaccines to establish long-term immunologic memory in patients with low-grade abnormalities of the cervix [63]. In this study 50 patients were randomly assigned to receive HPV16-SLP vaccination or placebo, followed by a vaccine or placebo booster one year later. Observed adverse effects included flu-like symptoms and injection site reactions. $97 \%$ of vaccinated patients showed a significant HPV16-specific immune response and the study demonstrated that two low-dose vaccinations of HPV16-SLP could induce a robust HPV16-specific $\mathrm{T}$ cell response, lasting up to one year. Although clinical and virological responses were not the objectives of the study, clinical regression and viral clearance in several patients were observed.

Another study investigated whether HPV16-SLP vaccination combined with standard carboplatin and paclitaxel (CarboTaxol) chemotherapy could improve immunity in patients with cervical cancer [64]. In addition, this study sought to determine the time point in which immunity is optimized and vaccine administration is most effective. Participating patients all had advanced, recurrent, or metastatic cervical cancer but were not required to have HPV16+ tumors. Patients were divided into two cohorts. Six patients were recruited for the first cohort and were administered CarboTaxol treatment once every three weeks for a total of six CarboTaxol treatments to determine which time point immunity is optimized. Levels of myeloid cells dropped, reaching their lowest levels 1 to 2 weeks after the second chemotherapy cycle in patients receiving CarboTaxol treatment. Furthermore, the decrease in myeloid cells corresponded with an increase in lymphoid cells. Although the relative frequencies of $\mathrm{CD} 4+$ and CD8+ $\mathrm{T}$ cells did not change, $\mathrm{T}$ cell function was enhanced. 13 patients and 19 healthy donors participated in the second cohort, which looked at whether CarboTaxol mediates normalizing of circulating immune cell frequencies. 12 patients received a single vaccination of HPV16-SLP 2 weeks after their second $(n=11)$ or third $(n=1)$ chemotherapy cycle. During CarboTaxol treatment lymphocyte count did not change; however, the number of circulating leukocytes increased significantly. Myeloid and lymphoid cell counts in CarboTaxol patients reached levels close to normalized levels of healthy donors. In addition, HPV16-SLP vaccination enhanced $\mathrm{T}$ cell response in patients, which remained the same in 11 patients after six cycles of chemotherapy. Significant regressions of tumors in patients were not observed, and 1 patient died 11 weeks after vaccination due to disease progression. However, vaccination was well tolerated and most adverse events observed were localized, injection site reactions. Additional clinical studies are being conducted to continue to evaluate the therapeutic potential of HPV-16 SLP vaccine. These includes a phase I/II trial in HIV+ male patient with HPV16+ AIN2/3 (NCT01923116), a phase II trial in patients with HPV-16+ incurable solid tumors in combination with Nivolumab (NCT02426892), and a phase I/II trial in female patients with HPV-16+ advanced or recurrent cervical cancer (NCT02128126).

PepCan is a therapeutic HPV vaccine consisting of four synthetic peptides covering HPV16 E6 and Candin, a novel adjuvant. The safety of PepCan was tested in a phase I clinical trial study in 31 patients with high grade squamous intraepithelial lesions (HSIL) [65]. PepCan was administered intradermally every three weeks at 50, $100,250,500 u g$ per peptide dose in six patients. 12 weeks after the last injection a loop electric excision procedure was performed to remove lesion tissues. In the final dose portion of the phase I clinical trial an additional ten patients with biopsy-confirmed HSIL (any HPV type) were vaccinated with $50 u g$ per peptide dose. Common adverse effects were mild to moderate injection site reactions, with no dose-limiting toxicities reported. The 50ug per peptide dosage demonstrated the best histological 
regression rate (50\% complete regression) and the most significant virological response (85\% viral clearance). Lastly, the viral load decreased in nine patients in whom HPV infection was detected at entry and exit. A new study is currently ongoing to further assess the efficacy of Pepcan + candin vaccination regimen in a phase II trial with cervical HSIL patients (NCT02481414).

Additionally, a phase I dose escalation trial using therapeutic HPV-peptide based vaccine with adjuvant Montanide and GMCSF (GL-0810) has been tested in five patients with recurrent/metastatic (RM) squamous cell carcinoma of the head and neck (SCCHN) [66]. GL-0810 was injected subcutaneously into participating patients. Overall, the vaccine was well tolerated with some adverse effects including erythema, pain, and itching at injection site. Four patients $(80 \%)$ with HPV16+ RM SCCHN generated T cell and antibody responses. Furthermore, no dose-limiting toxicities were observed. This trial demonstrated that GL-0810 is able to elicit an immune response and is well tolerated by patients with late stage SCCHN.

In addition to the vaccine candidates described above, a Phase I clinical trial has also been planned to evaluate the safety and therapeutic effect of PDS0101, a new therapeutic HPV vaccine candidate consist of Peptides from HPV-16 E6 and E7 as antigen and R-enantiomer of 1,2-dioleoyl-3-trimethylammonium-propane chloride as adjuvant, in female patients with high risk HPV infection or CIN1 (NCT02065973). Furthermore, a phase Ib/II trial has been planned to evaluate the therapeutic HPV vaccine DPX-E7, a HPV16-E7 aa11-19 nanomer peptide vaccine, in HLA-A*02 positive patients with incurable HPV16-related oropharyngeal, cervical, and anal cancer (NCT02865135).

Protein-based vaccines One benefit to using proteinbased vaccines is that they contain all human leukocyte antigen (HLA) epitopes. This avoids the limitation of MHC restriction, which is a setback to using peptidebased vaccines [67]. Protein-based vaccines, however, suffer from low immunogenicity and most are presented through the MHC class II pathway which activates the production of antibodies instead of generating a CTL response [58]. Strategies to overcome these problems focus on enhancing the MHC class I presentation. Adjuvants and immunostimulating molecules are added to proteinbased vaccines to increase endogenous processing, to further increase protein uptake by MHC class I, and to effectively target to DCs, which increase MHC class I presentation and activation of CD8+ T cells [57].

Therapeutic HVP vaccine TA-CIN is a subunit vaccine encompassing HPV16 E6E7L2 fusion protein [68]. TACIN has been proven immunogenic and safe in several phase I/II clinical trials [69-71]. A phase II study tested the ability of TA-CIN to be administered with imiquimod, a topical immunomodulatory, to treat patients with high grade vulva intraepithelial neoplasia (VIN) [72]. A total of 19 patients received imiquimod $5 \%$ cream and three intramuscular TA-CIN vaccinations (128ug/time) at 1-month intervals. Common adverse effects observed after imiquimod cream application included local inflammation, ulceration, malaise, and flu-like symptoms; however, no adverse effects associated with TA-CIN were observed. Twenty weeks after vaccination an increase in infiltrating $\mathrm{CD} 8+$ and $\mathrm{CD} 4+\mathrm{T}$ cells were observed, and at 52 weeks complete regression of VIN was observed in $63 \%$ of patients with $36 \%$ of lesions showed HPV16 clearance. In this study, antigen-specific immune responses in patients correlated with lesion regression. Currently, another Phase I study has been planned to evaluate the safety and efficacy of TA-CIN in combination with adjuvant GPI-0100 in patients with HPV16 associated cervical cancer (NCT02405221).

GTL001 (ProCervix) is a therapeutic HPV proteinbased vaccine that targets both HPV type 16 and 18 [73]. GTL001 is composed of recombinant HPV16 and HPV18 E7 proteins fused to catalytically inactive Bordetella pertussis CyaA expressed in E. coli. A phase I trial was conducted to examine the safety, tolerability, and immunogenicity of GTL001 in 47 women who had normal cytology but were positive for HPV16 or HPV18 infection. The participants were divided into four cohorts with two placebo sub-cohorts included within cohort three. Each patient was administered either 100 ug or 600ug of GTL001 with imiquimod. Patients treated with GTL001 experienced injection site reactions including pain, swelling, induration, tenderness, and itching; however, the study demonstrated that vaccination with GTL001 was relatively safe. GTL001 induced a humoral response to CyaA in all subjects but anti-E7 antibodies were not induced. All patients showed similar immunogenicity and tolerability. Patients in cohort 4 $(n=9)$ who received 600ug GTL001 powder + imiquimod experienced the highest HPV16/18 clearance rate. However, in the recently press release by GENTICEL regarding their interim (18 months) results for the double-blinded, placebo controlled, phase II studies involving the use of GTL001 in 233 patients with HPV16/ 18+ normal or abnormal cytology (NILM, ASCUS, or LSIL) (NCT01957878), no significant difference in viral clearance was observed in HPV-16/18 positive patients receiving GTL001 vaccine versus placebo.

Additional clinical trials have been planned to test the potential of other therapeutic HPV protein vaccine candidates. One of such include the use of TVGV-1, a fusion protein of HPV-16 E7 antigen with ER targeting sequence, in a phase IIa trial with HPV induced cervical HSIL patients (NCT02576561). 


\section{Nucleic acid-based vaccines}

DNA vaccines DNA vaccines have risen in popularity as an attractive and potentially effective approach for antigen-specific immunotherapy. DNA vaccines are safe, stable, easy to produce and can sustain antigen expression in cells for longer durations than RNA vaccines or protein vaccines. Furthermore, they do not produce neutralizing antibodies, which permits repeated vaccination [67]. There is a potential risk that administration of DNA encoding HPV oncogenes E6 and E7 may lead to cellular transformation. This problem was addressed by modifying E6 and E7 DNA to result in subsequent expression of proteins that are incapable of oncogenic transformation [74]. DNA vaccines involve the injection of plasmid DNA that encodes the antigen of interest, in our case HPV E6 and E7, into the host's cells.

DNA vaccines are often administered via intramuscular (IM) injection; however, myocytes are usually the cells that uptake the DNA after IM injection (for review see [67]). Although myocytes will express the target antigen, they are not professional APCs and therefore cannot activate a robust immune response [75]. DCs play an important role in presenting the antigen to naïve CD8+ cytotoxic $\mathrm{T}$ cells and do so through either phagocytosis and present exogenous antigen release from transfected myocytes on MHC class I through cross presentation, or direct transfection of DCs by vaccination leading to direct presentation to CD8+ T cells [76-78].

One limitation of DNA vaccines is that naked DNA is unable to amplify and spread from transfected cells to surrounding cells in vivo resulting in low immunogenicity. Consequently, several strategies have been developed to help overcome this hurdle (for review see [16]).

Therapeutic HPV DNA vaccines have undergone many clinical trials to evaluate the efficacy and safety of these vaccines. One such trial treated patients with HPV16-associated CIN2/3 lesions with heterologous prime-boost vaccination [79]. The DNA vaccine used in this study was pNGVL4a-sig/E7(detox)/HSP70, a plasmid encoding mutated form of HPV16-E7 linked to signal peptide and heat shock protein 70. pNGVL4a-sig/ E7(detox)/HSP70 DNA vaccine was previously shown to enhance the HPV-16 E7 antigen-specific T cell mediated immune responses in a preclinical model [80]. This study also used TA-HPV vaccine as a booster. Twelve patients received two intramuscular injections of pNGVL4a-sig/E7(detox)/HSP70 boosted with TA-HPV, at 1 month intervals. Reported adverse effects included tenderness, local reaction at injection site, blister with drainage, erythema, and pruritus. This study suggested that local immune responses are ultimately responsible for the therapeutic effects against target lesions and can lead to better clinical outcomes. The prime boost regimen of pNGVL4a-sig/E7(detox)/HSP70 DNA + TA-HPV viral vector vaccines is continued to be examined in a phase I trial in combination with topical imiquimod application in HPV16+ CIN3 patients (NCT00788164).

A more recent clinical study was conducted to evaluate the safety, efficacy, and immunogenicity of pNGVL4aCRT/E7(detox), a DNA plasmid vaccine [81]. pNGVL4aCRT/E7(detox) was administered to 32 patients with HPV16-associated CIN2/3 either intradermal, intramuscularly, or directly into the cervical lesion (intralesionally) three times at four week intervals. This study demonstrated that pNGVL4a-CRT/E7(detox) was well tolerated in patients, and vaccination via intralesional injection elicited stronger immune response and induced more CD8 + T cells. Another phase I trial on pNGVL4a-CRT/ E7(detox) DNA vaccine is still currently ongoing evaluating its safety and immunogenicity in patients with HPV16+ CIN2/3 lesions (NCT00988559).

A phase I clinical trial was conducted to evaluate the safety and efficacy of GX-188E, a therapeutic HPV DNA vaccine. The study was conducted in nine patients with high grade squamous intraepithelial lesions (HSIL/CIN3) [82]. GX-188E is a DNA vaccine engineered to express HPV16 and HPV18 proteins E6/E7 fused to the extracellular domain of Flt3L and signal sequence of plasminogen activator (tpa). Flt3L and tpa were included to enhance the potency of the vaccine through trafficking promotion and presentation of the fusion protein to the secretory pathway. Nine patients were administered GX$188 \mathrm{E}$ through intramuscular injection followed by electroporation to enhance immunogenicity. The results of this study demonstrated GX-188E to be safe and well tolerated by patients. Furthermore, all patients showed a statistically significant cellular immune response and three patients showed a weak antibody response against E7 protein. Genexine, Inc has planned two additional clinical trials on GX-188E, including a Phase II trial to be conducted in Eastern Europe targeting patients with HPV16/18+ CIN2, CIN2/3, or CIN3 lesions (NCT02596243), as well as a phase II trial to be conducted in South Korea targeting patients with HPV 16/18+ CIN3 lesions (NCT02139267).

An additional clinical study tested the therapeutic effects of HPV DNA vaccine VGX-3100. VGX-3100 is a combination of two plasmids encoding optimized HPV16 and 18 E6 and E7 antigens [83, 84]. VGX-3100 was administered through intramuscular injection followed by electroporation to 18 female patients who had been previously treated for CIN2/3 lesions [85]. Each patient received three rounds of vaccination, which was well tolerated with no observed dose-limiting toxicities. Adverse effects included injection site reaction, fever, pain during electroporation, and tenderness. Fourteen out of 18 patients (78 \%) showed induced HPVspecific CD8+ T cells with full cytolytic function, 17 out 
of 18 (94 \%) of patients had increased HPV16 E7 antibody titers, and all patients had increased HPV18 E7 antibody titers. Additionally, 12 patients (67 \%) had increased HPV16 E6 antibody titers, and seven (39 \%) patients had increased HPV18 E6 titers. These results exhibited the potential of VGX-3100 to induce a robust antigen-specific immune response and contribute to the eradication of HPV-infected cells and lesion regression. Furthermore, the results of this phase I study encouraged a follow up phase IIb clinical trial to further investigate the therapeutic efficacy of VGX-3100 DNA vaccine on CIN 2/3 lesions in a randomized, doubleblind, placebo-controlled study [86]. This study correspondingly demonstrated that patients vaccinated with VGX-3100 showed greater HPV-specific $\mathrm{T}$ cell and humoral responses. Inovio Pharmaceuticals has recently designed a new vaccine formulation INO-3112, incorporating the proprietary immune activator expressing IL12 (INO-9012) with the VGX-3100 DNA vaccine. This formulation is being tested in a phase I/IIA trial in patients with HPV associated head and neck squamous cell carcinoma (NCT02163057), a phase I/IIA trial in female patients with new, recurrent, or persistent cervical cancer (NCT02172911), as well as a phase II trial in patients with locally advanced cervical cancer who received standard of care chemoradiation (NCT02501278).

RNA vaccines Naked RNA replicon vaccines can be derived from several RNA viruses including Sindbis virus, Venezuela Equine Encephalitis virus, and SFV [34, 87, 88]. RNA replicons are capable of self-replication, which can lead to a sustained level of antigen expression and increased immunogenicity. Furthermore, RNA replicon vectors do not form viral particles, meaning they will not lead to the generation of neutralizing antibodies, permitting repeated administration. RNA replicons are also highly advantageous vaccination methods because they do not run the risk of chromosomal integration and cellular transformation that can occur by using DNA vaccines. One drawback to RNA replicons, however, is their low stability. One attempt to overcome this issue combined RNA replicons and DNA vaccine into DNA-launched RNA replicons, which are also referred to as 'suicidal DNA.' These 'suicidal DNA' trigger apoptosis in cells that uptake the injected DNA to prevent further integration and transformation of transfected cells [89]. However, because it will elicit apoptosis in transfected cells, including DCs, this approach has led to poor immunogencity. Several strategies have been created to address this issue. One example is the inclusion of genes encoding anti-apoptotic protein into 'suicidal DNA' to enhance survival of transfected APCs [90]. Another strategy employed to overcome apoptosis is the use of flavivirus Kunjin (KUN) vector to deliver replicons. Since KUN does not induce apoptosis in transfected cells, it enables the direct presentation by transfected DCs [91, 92]. Although RNA replicon vaccines have shown promising results in preclinical models and in other types of cancer setting [93], RNA vaccines targeting HPV antigens and HPVassociated diseases have not yet been explored in the clinical setting.

\section{Whole cell-based vaccines}

Dendritic cell-based vaccines DCs play an important role in immune system regulation, and they are commonly identified as the most efficient professional APCs [67]. DC-based vaccines have grown as the biological knowledge of DC and methods for preparing DCs ex vivo have improved. DC-based HPV vaccines involve loading the DCs with HPV antigens ex vivo and delivering those DCs to the infected host [94-98]. One benefit of DC-based vaccines is that DCs can serve as natural adjuvants to increase the potency of antigen-specific immunotherapy against cancer (for review see [99]). Because T cell-mediated apoptosis may limit DC lifespans, some strategies have been developed to prolong the survival of DCs. One such strategy is to transfect DCs with siRNAs targeting pro-apoptotic molecules. These strategies have been shown to generate a greater antigenspecific CD8+ T cell activation and antitumor effects in mice $[95,97,100]$.

Due to the therapeutic potential demonstrated by DCbased vaccines in preclinical models, further clinical trials were developed to test DC-based vaccine efficacy in humans. One such study was conducted to evaluate safety, toxicity, and immunogenicity of a DC-based vaccine in ten patients with stage Ib or IIa cervical cancer [101]. In this phase I, dose escalation trial autologous DCs were obtained from patients and pulsed with full length HPV16/18-E7 oncoprotein and keyhole limpet hemocyanin (KLH). The patients were then vaccinated with the pulsed DCs through subcutaneous injection. The DC-based vaccine used in the study was reported safe and well tolerated by patients, and resulted in minor local reactions, including erythema, swelling, and pruritus. There was an increase in HPV-specific humoral response and an increase in E7-specific CD4+ T cells in patients after vaccination.

An additional phase I clinical trial investigated the toxicity and immunogenicity of a DC-based vaccine in 14 patients with HPV+ advanced, recurrent cervical cancer [102]. Patients were separated into three treatment groups: saline only control, unprimed mature DC, and autologous tumor lysate primed mature DC. DCs were collected from each patient and pulsed with or without tumor lysate obtained from the same patient. Grade 0 and grade 1 toxicity, including itching at vaccination site, fever, chills, abdominal discomfort, and vomiting, were 
observed in three of the 14 patients, implying that the DC-based vaccine was well tolerated. No statistically significant increase in lymphocyte proliferation was observed in all patient groups.

In congruence with other vaccine types, DC-based vaccines have several limitations. DC-based vaccines are technically taxing, thus making them a poor choice for large-scale production. In addition, varying culturing techniques may lead to inconsistent vaccine quality and lack of standard criteria for vaccine evaluation. Lastly, the most effective administration route for DC-based vaccines has not yet been determined.

Tumor cell-based vaccines To create tumor cell-based vaccines, tumor cells are isolated and manipulated $e x$ vivo to express immune modulatory proteins, which can further enhance their immunogenicity in vivo. Cytokine genes IL-2, IL-12, and granulocyte macrophage colony stimulating factor (GMCSF) have been used to induce differentiation of naïve $\mathrm{T}$ cells into effector or helper $\mathrm{T}$ cells and to stimulate granulocyte production in HPV tumor cell-based vaccines in mice with HPV16 induced tumors $[103,104]$. One advantage to tumor cell vaccines is that tumor antigens do not need to be well defined; therefore, these vaccines may be able to cover a wider range of tumor antigens. Since HPV has well-known tumor-specific antigens, tumor cell-based vaccines may not be the most practical immunotherapy for HPVassociated cancers. In addition, tumor cell-based vaccines run the risk of implanting new cancers in patients. Due to the nature of these vaccines and their potential risks, the potency and purity of each vaccine must be individually tailored, making production expensive and time consuming. For these reasons tumor cell-based vaccines targeted against HPV have not yet been developed and tested in clinical studies.

\section{Conclusion}

The identification of high-risk HPV as the etiological factor for many diseases provides justification for the development of therapeutic HPV vaccines. The recent developments in the field as well as those discussed in this review have helped contribute to the foundational movement to eradicate HPV and HPV-associated diseases and malignancies. In this review we discussed the various methods of targeting HPV oncoproteins E6 and E7, which represent tumor-specific antigens and excellent targets for therapeutic HPV vaccines. Based on our own previous studies, and those conducted by other investigators in the field, we believe that the current therapeutic HPV vaccines mentioned in this review each possess advantages and limitations. Additional clinical studies are still necessary to further verify the antitumor efficacy of therapeutic HPV vaccines.
With continued efforts to improve and develop therapeutic treatment strategies, we anticipate the continued success of therapeutic HPV vaccines over the next few years, and beyond. We believe that therapeutic HPV vaccines will become clinically available in the near future and be offered alongside other available therapies for the control of HPV-associated diseases.

\begin{abstract}
Abbreviations
APC: Antigen presenting cell; B7-H1: B7 homolog-1; CarboTaxol: Carboplatin and paclitaxel; CIN: Cervical intraepithelial neoplasia; COX-2: Cyclooxygenase 2; CRT: Calreticulin; CTL: Cytotoxic T lymphocyte; DC: Dendritic cell; ER: Endoplasmic reticulum; GMCSF: Granulocyte macrophage colony stimulating factor; HBsAg: Hepatitis B virus surface antigen; HDACi: Histone deacetylase inhibitor; HLA: Human leukocyte antigen; HPV: Human papillomavirus; HPV16-SLP: HPV16 synthetic long-peptide vaccine; IDLV: Integrase defective lentiviral vector; IDO: Indoleamine 2,3-dioxygenase enzyme; IFN: Interferon; IFNy: IFN-gamma; IM: Intramuscular; ISG15: Interferon-stimulating gene 15; LLO: Listeriolysin O; MHC: Major histocompatibility complex; MICA/B: MHC class I polypeptide-related sequence A and B; PBMC: Peripheral blood mononuclear cells; RM: Recurrent/metastatic; rSFV: Recombinant Semliki Forest virus; SCCHN: Squamous cell carcinoma of the head and neck; SFV: Semliki Forest virus; STAT3: Signal transducer and activator of transcription 3; TCR: T cell receptor; TGF $\beta$ : Tumor growth factor-beta; TLR: Toll-like receptor; tpa: Signal sequence of plasminogen activator; VAIN: Vaginal intraepithelial neoplasia; VIN: Vulval intraepithelial neoplasia
\end{abstract}

\section{Acknowledgements \\ This review is not intended to be an encyclopedic one, and the authors apologize to those not cited.}

\section{Funding}

This work was funded by the United States National Institutes of Health (NIH) Cervical Cancer Specialized Program of Research Excellence (SPORE) (P50 CA098252), R01 grant (CA114425-01), 1R21 grant (CA194896), and 5R21 grant (Al109259).

\section{Availability of data and materials \\ Not applicable.}

Authors' contributions

$A Y, E F, T C W$, and CFH contributed in writing the manuscript. All authors read and approved the final manuscript.

\section{Authors' information}

Not applicable.

\section{Competing interests}

The authors declare that they have no competing interests.

\section{Consent for publication \\ Not applicable.}

Ethics approval and consent to participate

Not applicable.

\author{
Author details \\ ${ }^{1}$ Department of Pathology, Johns Hopkins University, Baltimore, MD, USA. \\ 2Department of Obstetrics and Gynecology, Johns Hopkins University, \\ Baltimore, MD, USA. ${ }^{3}$ Department of Molecular Microbiology and \\ Immunology, Johns Hopkins University, Baltimore, MD, USA. ${ }^{4}$ Department of \\ Oncology, Johns Hopkins University, Baltimore, MD, USA. ${ }^{5}$ The Johns Hopkins \\ University School of Medicine, CRB II Room 307, 1550 Orleans Street, \\ Baltimore, MD 21231, USA.
}

Received: 12 October 2016 Accepted: 26 October 2016 Published online: 04 November 2016 


\section{References}

1. Wakeham K, Kavanagh K. The burden of HPV-associated anogenital cancers. Curr Oncol Rep. 2014;16(9):402.

2. Forman D, de Martel C, Lacey CJ, Soerjomataram I, Lortet-Tieulent J, Bruni L, Vignat J, Ferlay J, Bray F, Plummer M, et al. Global burden of human papillomavirus and related diseases. Vaccine. 2012;30 Suppl 5:F12-23.

3. Maxwell JH, Grandis JR, and Ferris RL. HPV-Associated Head and Neck Cancer: Unique Features of Epidemiology and Clinical Management. Annual review of medicine. 2015

4. Mehanna H, Beech T, Nicholson T, El-Hariry I, McConkey C, Paleri V, Roberts S. Prevalence of human papillomavirus in oropharyngeal and nonoropharyngeal head and neck cancer-systematic review and meta-analysis of trends by time and region. Head Neck. 2013;35(5):747-55.

5. Egawa N, Egawa K, Griffin H, Doorbar J. Human Papillomaviruses; Epithelial Tropisms, and the Development of Neoplasia. Viruses. 2015;7(7):3863-90.

6. Munoz N, Bosch FX, de Sanjose S, Herrero R, Castellsague X, Shah KV, Snijders PJ, Meijer CJ. Epidemiologic classification of human papillomavirus types associated with cervical cancer. N Engl J Med. 2003;348(6):518-27.

7. Choi YJ, Park JS. Clinical significance of human papillomavirus genotyping. J Gynecol Oncol. 2016;27(2):e21.

8. Walboomers JM, Jacobs MV, Manos MM, Bosch FX, Kummer JA, Shah KV Snijders PJ, Peto J, Meijer CJ, Munoz N. Human papillomavirus is a necessary cause of invasive cervical cancer worldwide. J Pathol. 1999:189(1):12-9.

9. zur Hausen H. Papillomaviruses and cancer: from basic studies to clinical application. Nat Rev Cancer. 2002;2(5):342-50.

10. Harper DM, Williams KB. Prophylactic HPV vaccines: current knowledge of impact on gynecologic premalignancies. Discov Med. 2010;10(50):7-17.

11. Kash N, Lee MA, Kollipara R, Downing C, Guidry J, Tyring SK. Safety and efficacy data on vaccines and immunization to human papillomavirus. J Clin Med. 2015;4(4):614-33.

12. Ma B, Maraj B, Tran NP, Knoff J, Chen A, Alvarez RD, Hung CF, Wu TC. Emerging human papillomavirus vaccines. Expert Opin Emerg Drugs. 2012:17(4):469-92.

13. Ostor AG. Natural history of cervical intraepithelial neoplasia: a critical review. Int J Gynecol Pathol. 1993;12(2):186-92.

14. Ghittoni R, Accardi R, Chiocca S, Tommasino M. Role of human papillomaviruses in carcinogenesis. Ecancermedicalscience. 2015;9:526.

15. Doorbar J. Model systems of human papillomavirus-associated disease. J Pathol. 2016;238(2):166-79.

16. Yang A, Jeang J, Cheng K, Cheng T, Yang B, Wu TC, Hung CF. Current state in the development of candidate therapeutic HPV vaccines. Expert Rev Vaccines. 2016;15(8):989-1007.

17. Yao Y, Huang W, Yang X, Sun W, Liu X, Cun W, Ma Y. HPV-16 E6 and E7 protein $T$ cell epitopes prediction analysis based on distributions of HLA-A loci across populations: an in silico approach. Vaccine. 2013;31(18):2289-94.

18. Feltkamp MC, Smits HL, Vierboom MP, Minnaar RP, de Jongh BM, Drijfhout JW, ter Schegget J, Melief CJ, Kast WM. Vaccination with cytotoxic T lymphocyte epitope-containing peptide protects against a tumor induced by human papillomavirus type 16-transformed cells. Eur J Immunol. 1993;23(9):2242-9.

19. Kumar A, Hussain S, Yadav IS, Gissmann L, Natarajan K, Das BC, Bharadwaj M. Identification of human papillomavirus-16 E6 variation in cervical cancer and their impact on T and B cell epitopes. J Virol Methods. 2015:218:51-8.

20. Riemer AB, Keskin DB, Zhang G, Handley M, Anderson KS, Brusic V, Reinhold $B$, Reinherz EL. A conserved E7-derived cytotoxic T lymphocyte epitope expressed on human papillomavirus 16-transformed HLA-A2+ epithelial cancers. J Biol Chem. 2010:285(38):29608-22.

21. Mahdavi A, Monk BJ. Vaccines against human papillomavirus and cervical cancer: promises and challenges. Oncologist. 2005;10(7):528-38.

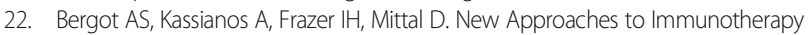
for HPV Associated Cancers. Cancers (Basel). 2011;3(3):3461-95.

23. Adachi K, Kawana K, Yokoyama T, Fujii T, Tomio A, Miura S, Tomio K, Kojima S, Oda K, Sewaki T, et al. Oral immunization with a Lactobacillus casei vaccine expressing human papillomavirus (HPV) type 16 E7 is an effective strategy to induce mucosal cytotoxic lymphocytes against HPV16 E7. Vaccine. 2010;28(16):2810-7.

24. Bermudez-Humaran LG, Cortes-Perez NG, Le Loir Y, Alcocer-Gonzalez JM, Tamez-Guerra RS, de Oca-Luna RM, Langella P. An inducible surface presentation system improves cellular immunity against human papillomavirus type 16 E7 antigen in mice after nasal administration with recombinant lactococci. J Med Microbiol. 2004;53(Pt 5):427-33.

25. Cortes-Perez NG, Azevedo V, Alcocer-Gonzalez JM, Rodriguez-Padilla C, Tamez-Guerra RS, Corthier G, Gruss A, Langella P, Bermudez-Humaran LG.
Cell-surface display of E7 antigen from human papillomavirus type-16 in Lactococcus lactis and in Lactobacillus plantarum using a new cell-wall anchor from lactobacilli. J Drug Target. 2005;13(2):89-98.

26. Sewell DA, Pan ZK, Paterson Y. Listeria-based HPV-16 E7 vaccines limit autochthonous tumor growth in a transgenic mouse model for HPV-16 transformed tumors. Vaccine. 2008:26(41):5315-20.

27. Schnupf P, Portnoy DA. Listeriolysin O: a phagosome-specific lysin. Microbes Infect. 2007;9(10):1176-87.

28. Chen Z, Ozbun L, Chong N, Wallecha A, Berzofsky JA, Khleif SN. Episomal expression of truncated listeriolysin $\mathrm{O}$ in LmddA-LLO-E7 vaccine enhances antitumor efficacy by preferentially inducing expansions of CD4 + FoxP3and CD8+ T cells. Cancer Immunol Res. 2014;2(9):911-22.

29. Peters C, Paterson Y. Enhancing the immunogenicity of bioengineered Listeria monocytogenes by passaging through live animal hosts. Vaccine. 2003:21(11-12):1187-94.

30. Maciag PC, Radulovic S, Rothman J. The first clinical use of a live-attenuated Listeria monocytogenes vaccine: a Phase I safety study of Lm-LLO-E7 in patients with advanced carcinoma of the cervix. Vaccine. 2009;27(30):3975-83.

31. Gunn GR, Zubair A, Peters C, Pan ZK, Wu TC, Paterson Y. Two Listeria monocytogenes vaccine vectors that express different molecular forms of human papilloma virus-16 (HPV-16) E7 induce qualitatively different T cell immunity that correlates with their ability to induce regression of established tumors immortalized by HPV-16. J Immunol. 2001;167(11):6471-9.

32. Olivier M, Tanner CE. The effect of cyclosporin A in murine visceral leishmaniasis. Trop Med Parasitol. 1989;40(1):32-8.

33. Krul MR, Tijhaar EJ, Kleijne JA, Van Loon AM, Nievers MG, Schipper H, Geerse L, Van der Kolk M, Steerenberg PA, Mooi FR, et al. Induction of an antibody response in mice against human papillomavirus (HPV) type 16 after immunization with HPV recombinant Salmonella strains. Cancer Immunol Immunother. 1996:43(1):44-8.

34. Cassetti MC, McElhiney SP, Shahabi V, Pullen JK, Le Poole IC, Eiben GL, Smith $L R$, Kast WM. Antitumor efficacy of Venezuelan equine encephalitis virus replicon particles encoding mutated HPV16 E6 and E7 genes. Vaccine. 2004; 22(3-4):520-7.

35. Gomez-Gutierrez JG, Elpek KG. Montes de Oca-Luna R, Shirwan H, Sam Zhou H, and McMasters KM. Vaccination with an adenoviral vector expressing calreticulinhuman papillomavirus 16 E7 fusion protein eradicates E7 expressing established tumors in mice. Cancer Immunol Immunother. 2007;56(7):997-1007.

36. Liu DW, Tsao YP, Kung JT, Ding YA, Sytwu HK, Xiao X, Chen SL. Recombinant adeno-associated virus expressing human papillomavirus type 16 E7 peptide DNA fused with heat shock protein DNA as a potential vaccine for cervical cancer. J Virol. 2000;74(6):2888-94.

37. Hsieh CJ, Kim TW, Hung CF, Juang J, Moniz M, Boyd DA, He L, Chen PJ, Chen $\mathrm{CH}, \mathrm{Wu} \mathrm{TC}$. Enhancement of vaccinia vaccine potency by linkage of tumor antigen gene to gene encoding calreticulin. Vaccine. 2004;22(29-30): 3993-4001.

38. Lamikanra A, Pan ZK, Isaacs SN, Wu TC, Paterson Y. Regression of established human papillomavirus type 16 (HPV-16) immortalized tumors in vivo by vaccinia viruses expressing different forms of HPV-16 E7 correlates with enhanced CD8(+) T-cell responses that home to the tumor site. J Virol. 2001; 75(20):9654-64.

39. Zurkova K, Babiarova K, Hainz P, Krystofova J, Kutinova L, Otahal P, Nemeckova S The expression of the soluble isoform of hFlt3 ligand by recombinant vaccinia virus enhances immunogenicity of the vector. Oncol Rep. 2009;21(5):1335-43.

40. Baez-Astua A, Herraez-Hernandez E, Garbi N, Pasolli HA, Juarez V, Zur Hausen $\mathrm{H}$, Cid-Arregui A. Low-dose adenovirus vaccine encoding chimeric hepatitis B virus surface antigen-human papillomavirus type 16 E7 proteins induces enhanced E7-specific antibody and cytotoxic T-cell responses. J Virol. 2005;79(20):12807-17.

41. Walczak M, Regts J, van Oosterhout AJ, Boon L, Wilschut J, Nijman HW, Daemen $\mathrm{T}$. Role of regulatory T-cells in immunization strategies involving a recombinant alphavirus vector system. Antivir Ther. 2011;16(2):207-18.

42. Riezebos-Brilman A, Regts J, Freyschmidt EJ, Dontje B, Wilschut J, Daemen T. Induction of human papilloma virus E6/E7-specific cytotoxic T-lymphocyte activity in immune-tolerant, E6/E7-transgenic mice. Gene Ther. 2005: 12(18):1410-4.

43. Riezebos-Brilman A, Regts J, Chen M, Wilschut J, Daemen T. Augmentation of alphavirus vector-induced human papilloma virus-specific immune and antitumour responses by co-expression of interleukin-12. Vaccine. 2009;27(5):701-7.

44. Ip PP, Boerma A, Walczak M, Oosterhuis K, Haanen JB, Schumacher TN, Nijman HW, Daemen T. Antigen design enhances the immunogenicity of 
Semliki Forest virus-based therapeutic human papillomavirus vaccines. Gene Ther. 2015;22(7):560-7.

45. Grasso F, Negri DR, Mochi S, Rossi A, Cesolini A, Giovannelli A, Chiantore MV, Leone P, Giorgi C, Cara A. Successful therapeutic vaccination with integrase defective lentiviral vector expressing nononcogenic human papillomavirus E7 protein. Int J Cancer. 2013;132(2):335-44.

46. Borysiewicz LK, Fiander A, Nimako M, Man S, Wilkinson GW, Westmoreland D, Evans AS, Adams M, Stacey SN, Boursnell ME, et al. A recombinant vaccinia virus encoding human papillomavirus types 16 and 18, E6 and E7 proteins as immunotherapy for cervical cancer. Lancet. 1996;347(9014):1523-7.

47. Brun JL, Dalstein V, Leveque J, Mathevet P, Raulic P, Baldauf JJ, Scholl S, Huynh B, Douvier S, Riethmuller D, et al. Regression of high-grade cervical intraepithelial neoplasia with TG4001 targeted immunotherapy. Am J Obstet Gynecol. 2011;204(2):169. e1-8.

48. Rosales C, Graham W, Rosas GA, Merchant H, Rosales R. A recombinant vaccinia virus containing the papilloma E2 protein promotes tumor regression by stimulating macrophage antibody-dependent cytotoxicity. Cancer Immunol Immunother. 2000;49(7):347-60.

49. Desaintes C, Demeret C, Goyat S, Yaniv M, Thierry F. Expression of the papillomavirus E2 protein in HeLa cells leads to apoptosis. EMBO J. 1997:16(3):504-14.

50. Arias-Pulido H, Peyton $\mathrm{CL}$, Joste NE, Vargas $\mathrm{H}$, Wheeler CM. Human papillomavirus type 16 integration in cervical carcinoma in situ and in invasive cervical cancer. J Clin Microbiol. 2006;44(5):1755-62.

51. Pett M, Coleman N. Integration of high-risk human papillomavirus: a key event in cervical carcinogenesis? J Pathol. 2007;212(4):356-67.

52. Gray E, Pett MR, Ward D, Winder DM, Stanley MA, Roberts I, Scarpini CG, Coleman N. In vitro progression of human papillomavirus 16 episomeassociated cervical neoplasia displays fundamental similarities to integrantassociated carcinogenesis. Cancer Res. 2010;70(10):4081-91.

53. Rosales R, Lopez-Contreras M, Rosales C, Magallanes-Molina JR, GonzalezVergara R, Arroyo-Cazarez JM, Ricardez-Arenas A, Del Follo-Valencia A, Padilla-Arriaga S, Guerrero MV, et al. Regression of human papillomavirus intraepithelial lesions is induced by MVA E2 therapeutic vaccine. Hum Gene Ther. 2014;25(12):1035-49.

54. Kaufmann AM, Stern PL, Rankin EM, Sommer H, Nuessler V, Schneider A, Adams M, Onon TS, Bauknecht T, Wagner U, et al. Safety and immunogenicity of TAHPV, a recombinant vaccinia virus expressing modified human papillomavirus (HPV)-16 and HPV-18 E6 and E7 genes, in women with progressive cervical cancer. Clin Cancer Res. 2002:8(12):3676-85.

55. Baldwin PJ, van der Burg SH, Boswell CM, Offringa R, Hickling JK, Dobson J, Roberts JS, Latimer JA, Moseley RP, Coleman N, et al. Vaccinia-expressed human papillomavirus 16 and $18 \mathrm{e} 6$ and e7 as a therapeutic vaccination for vulval and vaginal intraepithelial neoplasia. Clin Cancer Res. 2003;9(14):5205-13.

56. Chang CL, Ma B, Pang X, Wu TC, Hung CF. Treatment with cyclooxygenase2 inhibitors enables repeated administration of vaccinia virus for control of ovarian cancer. Mol Ther. 2009:17(8):1365-72.

57. Lin K, Doolan K, Hung CF, Wu TC. Perspectives for preventive and therapeutic HPV vaccines. J Formos Med Assoc. 2010;109(1):4-24.

58. Su JH, Wu A, Scotney E, Ma B, Monie A, Hung CF, Wu TC. Immunotherapy for cervical cancer: research status and clinical potential. BioDrugs. 2010; 24(2):109-29.

59. de Vos van Steenwijk PJ, Ramwadhdoebe TH, Lowik MJ, van der Minne CE, der Meer DM B-V, Fathers LM, Valentijn AR, Oostendorp J, Fleuren GJ, Hellebrekers BW, et al. A placebo-controlled randomized HPV16 synthetic long-peptide vaccination study in women with high-grade cervical squamous intraepithelial lesions. Cancer Immunol Immunother. 2012;61(9):1485-92.

60. Kenter GG, Welters MJ, Valentijn AR, Lowik MJ, der Meer DM B-V, Vloon AP, Essahsah F, Fathers LM, Offringa R, Drijfhout JW, et al. Vaccination against HPV-16 oncoproteins for vulvar intraepithelial neoplasia. N Engl J Med. 2009; 361(19):1838-47.

61. Van Poelgeest MI, Welters MJ, Van Esch EM, Stynenbosch LF, Kerpershoek G, van Meerten EL VP, Van den Hende M, Lowik MJ, der Meer DM B-V, Fathers LM, et al. HPV16 synthetic long peptide (HPV16-SLP) vaccination therapy of patients with advanced or recurrent HPV16-induced gynecological carcinoma, a phase II trial. J Transl Med. 2013;11:88.

62. Zwaveling S, Ferreira Mota SC, Nouta J, Johnson M, Lipford GB, Offringa R, van der Burg SH, Melief CJ. Established human papillomavirus type 16expressing tumors are effectively eradicated following vaccination with long peptides. J Immunol. 2002;169(1):350-8.
63. de Vos van Steenwijk PJ, van Poelgeest MI, Ramwadhdoebe TH, Lowik MJ, der Meer DM B-V, Van der Minne CE, Loof NM, Stynenbosch LF, Fathers LM, Valentijn AR, et al. The long-term immune response after HPV16 peptide vaccination in women with low-grade pre-malignant disorders of the uterine cervix: a placebo-controlled phase II study. Cancer Immunol Immunother. 2014;63(2):147-60.

64. Welters MJ, van der Sluis TC, van Meir H, Loof NM, van Ham VJ, van Duikeren S, Santegoets SJ, Arens R, de Kam ML, Cohen AF, et al. Vaccination during myeloid cell depletion by cancer chemotherapy fosters robust $\mathrm{T}$ cell responses. Sci Transl Med. 2016;8(334):334ra52.

65. Coleman HN, Greenfield WW, Stratton SL, Vaughn R, Kieber A, MoermanHerzog AM, Spencer HJ, Hitt WC, Quick CM, Hutchins LF, et al. Human papillomavirus type 16 viral load is decreased following a therapeutic vaccination. Cancer Immunol Immunother. 2016;65(5):563-73.

66. Zandberg DP, Rollins S, Goloubeva O, Morales RE, Tan M, Taylor R, Wolf JS, Schumaker LM, Cullen K, Zimrin A, et al. A phase I dose escalation trial of MAGE-A3- and HPV16-specific peptide immunomodulatory vaccines in patients with recurrent/metastatic (RM) squamous cell carcinoma of the head and neck (SCCHN). Cancer Immunol Immunother. 2015;64(3):367-79.

67. Lee SJ, Yang A, Wu TC, Hung CF. Immunotherapy for human papillomavirusassociated disease and cervical cancer: review of clinical and translational research. J Gynecol Oncol. 2016;27(5):e51.

68. van der Burg SH, Kwappenberg KM, O'Neill T, Brandt RM, Melief CJ, Hickling JK, Offringa R. Pre-clinical safety and efficacy of TA-CIN, a recombinant HPV16 L2E6E7 fusion protein vaccine, in homologous and heterologous prime-boost regimens. Vaccine. 2001;19(27):3652-60.

69. Davidson EJ, Faulkner RL, Sehr P, Pawlita M, Smyth LJ, Burt DJ, Tomlinson AE, Hickling J, Kitchener HC, Stern PL. Effect of TA-CIN (HPV 16 L2E6E7) booster immunisation in vulval intraepithelial neoplasia patients previously vaccinated with TA-HPV (vaccinia virus encoding HPV 16/18 E6E7). Vaccine. 2004;22(21-22):2722-9

70. de Jong A, O'Neill T, Khan AY, Kwappenberg KM, Chisholm SE, Whittle NR, Dobson JA, Jack LC, St Clair Roberts JA, Offringa R, et al. Enhancement of human papillomavirus (HPV) type 16 E6 and E7-specific T-cell immunity in healthy volunteers through vaccination with TA-CIN, an HPV16 L2E7E6 fusion protein vaccine. Vaccine. 2002;20(29-30):3456-64.

71. Smyth LI, Van Poelgeest MI, Davidson EJ, Kwappenberg KM, Burt D, Sehr P, Pawlita M, Man S, Hickling JK, Fiander AN, et al. Immunological responses in women with human papillomavirus type 16 (HPV-16)-associated anogenital intraepithelial neoplasia induced by heterologous prime-boost HPV-16 oncogene vaccination. Clin Cancer Res. 2004;10(9):2954-61.

72. Daayana S, Elkord E, Winters U, Pawlita M, Roden R, Stern PL, Kitchener HC. Phase II trial of imiquimod and HPV therapeutic vaccination in patients with vulval intraepithelial neoplasia. Br J Cancer. 2010;102(7):1129-36.

73. Van Damme P, Bouillette-Marussig M, Hens A, De Coster I, Depuydt C, Goubier A, Van Tendeloo V, Cools N, Goossens H, Hercend T, et al. GTL001, a therapeutic vaccine for women infected with human papillomavirus 16 or 18 and normal cervical cytology: results of a phase I clinical trial. Clin Cancer Res. 2016;22(13):3238-48.

74. Kim JW, Hung CF, Juang J, He L, Kim TW, Armstrong DK, Pai SI, Chen PJ, Lin CT, Boyd DA, et al. Comparison of HPV DNA vaccines employing intracellular targeting strategies. Gene Ther. 2004;11(12):1011-8.

75. Fu TM, Ulmer JB, Caulfield MJ, Deck RR, Friedman A, Wang S, Liu X, Donnelly JJ, Liu MA. Priming of cytotoxic T lymphocytes by DNA vaccines: requirement for professional antigen presenting cells and evidence for antigen transfer from myocytes. Mol Med. 1997;3(6):362-71.

76. Chattergoon MA, Robinson TM, Boyer JD, Weiner DB. Specific immune induction following DNA-based immunization through in vivo transfection and activation of macrophages/antigen-presenting cells. J Immunol. 1998;160(12):5707-18.

77. Dupuis M, Denis-Mize K, Woo C, Goldbeck C, Selby MJ, Chen M, Otten GR, Ulmer JB, Donnelly JJ, Ott G, et al. Distribution of DNA vaccines determines their immunogenicity after intramuscular injection in mice. J Immunol. 2000;165(5):2850-8.

78. Porgador A, Invine KR, Iwasaki A, Barber BH, Restifo NP, Germain RN. Predominant role for directly transfected dendritic cells in antigen presentation to CD8+ T cells after gene gun immunization. J Exp Med. 1998;188(6):1075-82.

79. Maldonado L, Teague JE, Morrow MP, Jotova I, Wu TC, Wang C, Desmarais C, Boyer JD, Tycko B, Robins HS, et al. Intramuscular therapeutic vaccination targeting HPV16 induces T cell responses that localize in mucosal lesions. Sci Transl Med. 2014;6(221):221ra13. 
80. Trimble C, Lin CT, Hung CF, Pai S, Juang J, He L, Gillison M, Pardoll D, Wu L, Wu TC. Comparison of the CD8+ T cell responses and antitumor effects generated by DNA vaccine administered through gene gun, biojector, and syringe. Vaccine. 2003;21(25-26):4036-42.

81. Alvarez RD, Huh WK, Bae S, Lamb Jr LS, Conner MG, Boyer J, Wang C, Hung CF, Sauter $E$, Paradis $M$, et al. A pilot study of pNGVL4a-CRT/E7(detox) for the treatment of patients with HPV16+ cervical intraepithelial neoplasia 2/3 (CIN2/3). Gynecol Oncol. 2016;140(2):245-52.

82. Kim TJ, Jin HT, Hur SY, Yang HG, Seo YB, Hong SR, Lee CW, Kim S, Woo JW, Park KS, et al. Clearance of persistent HPV infection and cervical lesion by therapeutic DNA vaccine in CIN3 patients. Nat Commun. 2014;5:5317.

83. Yan J, Harris K, Khan AS, Draghia-Akli R, Sewell D, Weiner DB. Cellular immunity induced by a novel HPV18 DNA vaccine encoding an E6/E7 fusion consensus protein in mice and rhesus macaques. Vaccine. 2008;26(40):5210-5.

84. Yan J, Reichenbach DK, Corbitt N, Hokey DA, Ramanathan MP, McKinney KA, Weiner DB, Sewell D. Induction of antitumor immunity in vivo following delivery of a novel HPV-16 DNA vaccine encoding an E6/E7 fusion antigen. Vaccine. 2009;27(3):431-40.

85. Bagarazzi ML, Yan J, Morrow MP, Shen X, Parker RL, Lee JC, Giffear M, Pankhong P, Khan AS, Broderick KE, et al. Immunotherapy against HPV16/18 generates potent TH1 and cytotoxic cellular immune responses. Sci Transl Med. 2012;4: 155 ra38.

86. Trimble CL, Morrow MP, Kraynyak KA, Shen X, Dallas M, Yan J, Edwards L, Parker RL, Denny L, Giffear M, et al. Safety, efficacy, and immunogenicity of VGX-3100, a therapeutic synthetic DNA vaccine targeting human papillomavirus 16 and 18 E6 and E7 proteins for cervical intraepithelial neoplasia 2/3: a randomised, double-blind, placebo-controlled phase $2 \mathrm{~b}$ trial. Lancet. 2015;386(10008):2078-88.

87. Berglund P, Quesada-Rolander M, Putkonen P, Biberfeld G, Thorstensson R, Liljestrom P. Outcome of immunization of cynomolgus monkeys with recombinant Semliki Forest virus encoding human immunodeficiency virus type 1 envelope protein and challenge with a high dose of SHIV-4 virus. AIDS Res Hum Retroviruses. 1997;13(17):1487-95.

88. Cheng WF, Hung CF, Hsu KF, Chai CY, He L, Polo JM, Slater LA, Ling M, Wu TC. Cancer immunotherapy using Sindbis virus replicon particles encoding a VP22-antigen fusion. Hum Gene Ther. 2002;13(4):553-68.

89. Hsu KF, Hung CF, Cheng WF, He L, Slater LA, Ling M, Wu TC. Enhancement of suicidal DNA vaccine potency by linking Mycobacterium tuberculosis heat shock protein 70 to an antigen. Gene Ther. 2001;8(5):376-83.

90. Kim TW, Hung CF, Juang J, He L, Hardwick JM, Wu TC. Enhancement of suicidal DNA vaccine potency by delaying suicidal DNA-induced cell death. Gene Ther. 2004;11(3):336-42.

91. Varnavski AN, Young PR, Khromykh AA. Stable high-level expression of heterologous genes in vitro and in vivo by noncytopathic DNA-based Kunjin virus replicon vectors. J Virol. 2000;74(9):4394-403.

92. Herd KA, Harvey T, Khromykh AA, Tindle RW. Recombinant Kunjin virus replicon vaccines induce protective T-cell immunity against human papillomavirus 16 E7-expressing tumour. Virology. 2004;319(2):237-48.

93. Sebastian M, Papachristofilou A, Weiss C, Fruh M, Cathomas R, Hilbe W, Wehler T, Rippin G, Koch SD, Scheel B, et al. Phase lb study evaluating a self-adjuvanted mRNA cancer vaccine (RNActive(R)) combined with loca radiation as consolidation and maintenance treatment for patients with stage IV non-small cell lung cancer. BMC Cancer. 2014;14:748.

94. Benencia F, Courreges MC, Coukos G. Whole tumor antigen vaccination using dendritic cells: comparison of RNA electroporation and pulsing with UV-irradiated tumor cells. J Transl Med. 2008;6:21.

95. Kim JH, Kang TH, Noh KH, Bae HC, Kim SH, Yoo YD, Seong SY, Kim TW. Enhancement of dendritic cell-based vaccine potency by anti-apoptotic siRNAs targeting key pro-apoptotic proteins in cytotoxic CD8(+) T cellmediated cell death. Immunol Lett. 2009;122(1):58-67.

96. Mackova J, Kutinova L, Hainz P, Krystofova J, Sroller V, Otahal P, Gabriel P, Nemeckova S. Adjuvant effect of dendritic cells transduced with recombinant vaccinia virus expressing HPV16-E7 is inhibited by co-expression of IL12. Int J Oncol. 2004;24(6):1581-8.

97. Peng S, Kim TW, Lee JH, Yang M, He L, Hung CF, Wu TC. Vaccination with dendritic cells transfected with BAK and BAX siRNA enhances antigenspecific immune responses by prolonging dendritic cell life. Hum Gene Ther. 2005;16(5):584-93.

98. Wang TL, Ling M, Shih IM, Pham T, Pai SI, Lu Z, Kurman RJ, Pardoll DM, Wu TC. Intramuscular administration of E7-transfected dendritic cells generates the most potent E7-specific anti-tumor immunity. Gene Ther. 2000;7(9):726-33.
99. Santin AD, Bellone S, Roman JJ, Burnett A, Cannon MJ, Pecorelli S. Therapeutic vaccines for cervical cancer: dendritic cell-based immunotherapy. Curr Pharm Des. 2005;11(27):3485-500.

100. Ahn $\mathrm{YH}$, Hong $\mathrm{SO}$, Kim JH, Noh KH, Song KH, Lee $\mathrm{YH}$, Jeon JH, Kim DW, Seo JH, Kim TW. The siRNA cocktail targeting interleukin 10 receptor and transforming growth factor-beta receptor on dendritic cells potentiates tumour antigen-specific CD8(+) T cell immunity. Clin Exp Immunol. 2015;181(1):164-78.

101. Santin AD, Bellone S, Palmieri M, Zanolini A, Ravaggi A, Siegel ER, Roman JJ, Pecorelli S, Cannon MJ. Human papillomavirus type 16 and 18 E7-pulsed dendritic cell vaccination of stage IB or IIA cervical cancer patients: a phase I escalating-dose trial. J Virol. 2008;82(4):1968-79.

102. Ramanathan $P$, Ganeshrajah S, Raghanvan RK, Singh SS, Thangarajan R. Development and clinical evaluation of dendritic cell vaccines for HPV related cervical cancer-a feasibility study. Asian Pac J Cancer Prev. 2014; 15(14):5909-16

103. Chang EY, Chen $\mathrm{CH}$, Ji H, Wang TL, Hung K, Lee BP, Huang AY, Kurman RJ, Pardoll DM, Wu T. Antigen-specific cancer immunotherapy using a GM-CSF secreting allogeneic tumor cell-based vaccine. Int J Cancer. 2000;86(5):725-30.

104. Mikyskova R, Indrova M, Simova J, Jandlova T, Bieblova J, Jinoch P, Bubenik J, Vonka $\mathrm{V}$. Treatment of minimal residual disease after surgery or chemotherapy in mice carrying HPV16-associated tumours: cytokine and gene therapy with IL-2 and GM-CSF. Int J Oncol. 2004;24(1):161-7.

\section{Submit your next manuscript to BioMed Central and we will help you at every step:}

- We accept pre-submission inquiries

- Our selector tool helps you to find the most relevant journal

- We provide round the clock customer support

- Convenient online submission

- Thorough peer review

- Inclusion in PubMed and all major indexing services

- Maximum visibility for your research

Submit your manuscript at www.biomedcentral.com/submit
C Biomed Central 